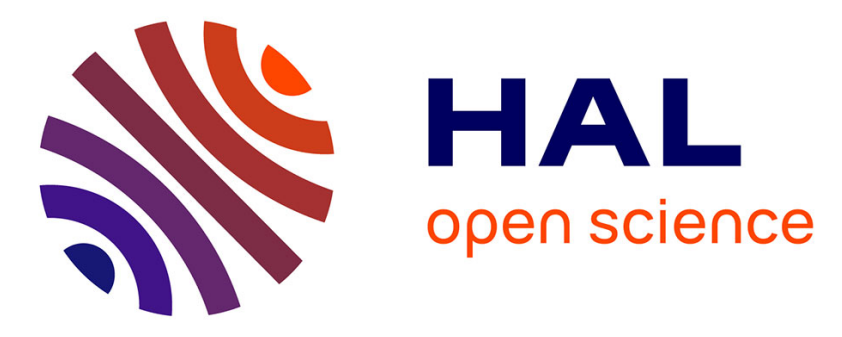

\title{
Experimental and theoretical study of the $[3+2]$ cycloaddition of carbonyl ylides with alkynes
}

Ghenia Bentabed-Ababsa, Samira Hamza-Reguig, Aïcha Derdour, Luis R.

Domingo, José A. Sáez, Thierry Roisnel, Vincent Dorcet, Ekhlass Nassar, Florence Mongin

\section{To cite this version:}

Ghenia Bentabed-Ababsa, Samira Hamza-Reguig, Aïcha Derdour, Luis R. Domingo, José A. Sáez, et al. Experimental and theoretical study of the [3+2] cycloaddition of carbonyl ylides with alkynes. Organic \& Biomolecular Chemistry, 2012, 10, pp.8434. 10.1039/C2OB26442K . hal-01002537

\section{HAL Id: hal-01002537 https://hal.science/hal-01002537}

Submitted on 6 Jun 2014

HAL is a multi-disciplinary open access archive for the deposit and dissemination of scientific research documents, whether they are published or not. The documents may come from teaching and research institutions in France or abroad, or from public or private research centers.
L'archive ouverte pluridisciplinaire HAL, est destinée au dépôt et à la diffusion de documents scientifiques de niveau recherche, publiés ou non, émanant des établissements d'enseignement et de recherche français ou étrangers, des laboratoires publics ou privés. 


\title{
Experimental and theoretical study of the [3+2] cycloaddition of carbonyl ylides with alkynes
}

\author{
Ghenia Bentabed-Ababsa, ${ }^{* a, b}$ Samira Hamza-Reguig, ${ }^{a}$ Aïcha Derdour, ${ }^{a}$ Luis R. Domingo, ${ }^{* c}$ José A. Sáez, \\ Thierry Roisnel, ${ }^{d}$ Vincent Dorcet, ${ }^{d}$ Ekhlass Nassar ${ }^{e}$ and Florence Mongin* ${ }^{b}$
}

\author{
${ }_{5}$ Received (in $\left.X X X, X X X\right)$ Xth $X X X X X X X X X 20 X X$, Accepted Xth $X X X X X X X X X 20 X X$ \\ DOI: 10.1039/b000000x
}

The [3+2] cycloaddition reaction between carbonyl ylides generated from epoxides and alkynes (phenylacetylene, methyl propiolate, methyl but-2-ynoate and methyl 3-phenylpropiolate) to give substituted 2,5-dihydrofurans was investigated. The effect of indium(III) chloride on the outcome of the

10 reaction was studied in the case of phenylacetylene and methyl propiolate. The thermal reaction between the carbonyl ylide coming from 2,2-dicyano-3-phenyloxirane and both methyl propiolate and methyl but2-ynoate was theoretically investigated using DFT methods in order to explain the reactivity and regioselectivity observed.

\section{Introduction}

${ }_{15}$ Cycloaddition reactions are one of the most important synthetic processes, with both synthetic and mechanistic interest in organic chemistry. Among them, [3+2] cycloaddition (32CA) reactions, also named 1,3-dipolar cycloadditions, whose general concept was introduced by Huisgen and co-workers in 1960s, ${ }^{1}$ are 20 versatile tools for building five-membered heterocycles, and current understanding of the underlying principles in these reactions has grown from a fruitful interplay between theory and experiment. $^{2}$

Carbonyl ylides, generated by thermal ring opening of 25 epoxides, are known to react with $\pi$-bonds of alkynes, ${ }^{3}$ alkenes, ${ }^{3 a, b, 4}$ imines, $^{5}$ aldehydes ${ }^{5 c, 6}$ and ketones, ${ }^{7}$ and thioketones, ${ }^{8}$ affording highly substituted dihydrofurans, tetrahydrofurans, oxazolidines, dioxolanes, and oxathiolanes, respectively. Following recent studies of the 32CA reactions 30 between, on the one hand, carbonyl ylides and, on the other hand, aldehydes, ${ }^{5 c}$ imines, ${ }^{5 c}$ and ketones, ${ }^{7}$ in which we have performed theoretical calculations using density functional theory (DFT) methods to depict the mechanism of these reactions, we here report our studies concerning the reactions involving 35 unsymmetrical alkynes.

Since the first thermal reactions between carbonyl ylides, generated from epoxides, and activated alkynes (such as methyl acetylenedicarboxylate) reported more than 40 years ago, ${ }^{3 a, b}$ few studies have been devoted to such an access to dihydrofurans. ${ }^{3 c-e}$

40 In particular, it was of interest to study, in the light of DFT calculations, the regioselectivity results obtained by involving unsymmetrical alkynes in the reaction with carbonyl ylides.

\section{Results and discussion}

Synthetic aspects
${ }_{45}$ We first considered 32CA reactions between 2,2-dicyano-3-(4substituted)phenyloxiranes $\mathbf{1} \mathbf{a}-\mathbf{c}^{9}$ and terminal alkynes. Using phenylacetylene ( 2,5 equiv), monitoring the conversion to the corresponding 2,5-dihydrofurans by TLC showed that the reactions carried out in refluxing toluene were complete after 50 about $40 \mathrm{~h}$. NMR analysis of the crude obtained after removal of the solvent showed the presence of two regioisomers in each case, with ratios of $84: 16,84: 16$ and 75:25 respectively obtained using 1a $(\mathrm{X}=\mathrm{H}), \mathbf{1 b}(\mathrm{X}=\mathrm{Cl})$ and $\mathbf{1 c}(\mathrm{X}=\mathrm{OMe})$. The major products $\mathbf{3}$ were purified by column chromatography over silica ${ }_{55}$ gel, in yields ranging from 40 to $52 \%$ whereas 3 'b was the only minor product isolated (12\% yield). The observed ${ }^{1} \mathrm{H}$ NMR coupling constants of 1.8 and $2.1 \mathrm{~Hz}$ were respectively attributed to ${ }^{\mathrm{H}} J_{4-5}$ (major regioisomer 3 ) and ${ }^{\mathrm{H}} J_{3-5}$ (minor regioisomer $3^{\prime}$ ) on the based of a previous study. ${ }^{10}$ The major regioisomers 3 were 60 then identified unequivocally by X-ray structure analysis (Table 1, entries 1-3). $\dagger$

Table 1 Cycloaddition reaction between carbonyl ylides generated from the epoxides $\mathbf{1}$ and phenylacetylene (2).
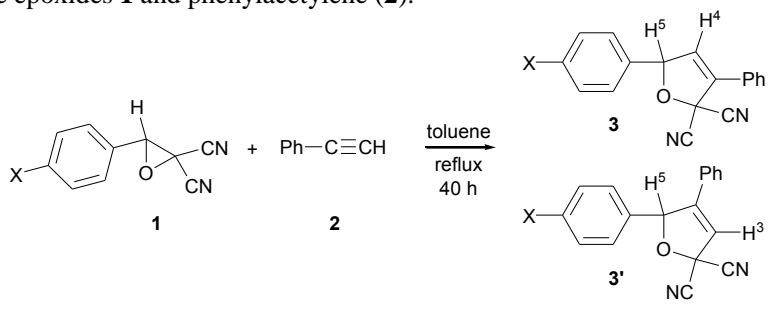

\begin{tabular}{lllll}
\hline entry & $\mathrm{X}(\mathbf{1})$ & catalyst & $\mathbf{3 : 3}$ ratio & $\operatorname{product}(\mathrm{s})$, yield(s) $(\%)$ \\
\hline 1 & $\mathrm{H}(\mathbf{1 a})$ & - & $84: 16$ & $\mathbf{3 a}, 40$ \\
2 & $\mathrm{Cl}(\mathbf{1 b})$ & - & $84: 16$ & $\mathbf{3 b}, 52 ; \mathbf{3}^{\prime} \mathbf{b}, 12$ \\
3 & $\mathrm{MeO}(\mathbf{1 c})$ & - & $75: 25$ & $\mathbf{3 c}, 50$ \\
4 & $\mathrm{H}(\mathbf{1 a})$ & $\mathrm{InCl}_{3}(0.1$ equiv) & $90: 10$ & $\mathbf{3 a}, 60$ \\
5 & $\mathrm{Cl}(\mathbf{1 b})$ & $\mathrm{InCl}_{3}(0.1$ equiv) & $89: 11$ & $\mathbf{3 b}, 64$ \\
6 & $\mathrm{MeO}(\mathbf{1 c})$ & $\mathrm{InCl}_{3}(0.1$ equiv) & $83: 17$ & $\mathbf{3 c}, 60$ \\
\hline
\end{tabular}


The same reactions have then been repeated, but in the presence of indium(III) chloride ( 0.1 equiv) which has been recognized as a suitable catalyst for cycloaddition reactions. ${ }^{11}$ Shortened reaction times of $29 \mathrm{~h}, 27 \mathrm{~h}$ and $20 \mathrm{~h}$, increased 3:3' 5 ratios of 90:10, 89:11 and 83:17, and higher yields of $\mathbf{3}$ (60 to $64 \%)$ were respectively noted using $\mathbf{1 a}(\mathrm{X}=\mathrm{H}), \mathbf{1 b}(\mathrm{X}=\mathrm{Cl})$ and 1c $(\mathrm{X}=\mathrm{OMe})$ under these conditions using 4 equiv of phenylacetylene (Table 1, entries 4-6).

We next turned to the reaction of methyl propiolate (4) with 10 the 2,2-dicyano-3-(4-substituted)phenyloxiranes 1a,b (4 equiv) and 1c (1 equiv) under the conditions used before. Without catalyst, NMR analysis of the crudes showed the formation of two regioisomers in 24:76, 26:74 and 29:71 ratios, using 19 (48 h reaction time for complete conversion), $\mathbf{1 b}(48 \mathrm{~h})$ and $\mathbf{1 c}(24 \mathrm{~h})$ 15 respectively. They were separated by column chromatography over silica gel, and isolated in yields ranging from 10 to $12 \%$ and 40 to $65 \%$ for the major and minor isomer, respectively. As before, ${ }^{10}$ the major compounds with the higher 2,5-dihydrofuran ${ }^{1} \mathrm{H}$ NMR coupling constants $(2.1 \mathrm{~Hz})$ were assigned to the 420 substituted regioisomers $5^{\prime}\left({ }^{\mathrm{H}} J_{3-5}\right)$, and the minor compounds with the lower 2,5-dihydrofuran ${ }^{1} \mathrm{H}$ NMR coupling constants (1.5-1.8 $\mathrm{Hz})$ to the 3 -substituted regioisomers $5\left({ }^{\mathrm{H}} J_{4-5}\right)$. This was corroborated by NMR HMQC sequences performed on 5'c and $\mathbf{5 c}$, and the structures of $\mathbf{5}$ 'a and $\mathbf{5 b}$ were confirmed by X-ray 25 diffraction data (Table 2, entries 1-3). $\dagger$ In the presence of indium(III) chloride ( 0.1 equiv), the reaction times were slightly shortened (36 h in the case of $\mathbf{1 a}, \mathbf{b}$ and $20 \mathrm{~h}$ with 1c), as well as the regioselectivities (Table 2, entries 4-6).

Table 2 Cycloaddition reaction between carbonyl ylides generated from the epoxides $\mathbf{1}$ and methyl propiolate (4).
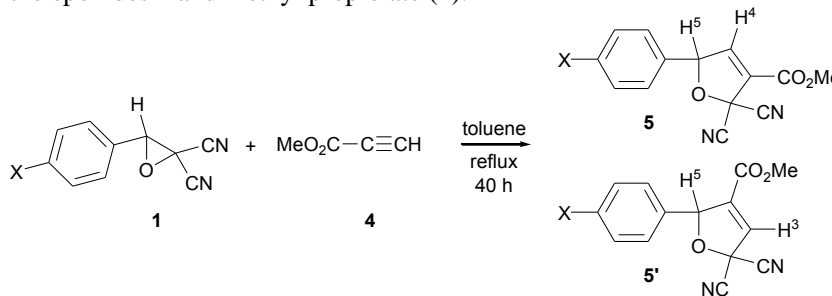

\begin{tabular}{lllll}
\hline entry & $\mathrm{X}(\mathbf{1})$ & catalyst & $\mathbf{5 : 5}$ ratio & product(s), yield(s) (\%) \\
\hline 1 & $\mathrm{H}(\mathbf{1 a})$ & - & $24: 76$ & $\mathbf{5 a}, 12 ; \mathbf{5} \mathbf{a}, 40$ \\
2 & $\mathrm{Cl}(\mathbf{1 b})$ & - & $26: 74$ & $\mathbf{5 b}, 10 ; \mathbf{5} ' \mathbf{b}, 54$ \\
3 & $\mathrm{MeO}(\mathbf{1 c})$ & - & $29: 71$ & $\mathbf{5 c}, 11 ; \mathbf{5} ' \mathbf{c}, 65$ \\
\hline 4 & $\mathrm{H}(\mathbf{1 a})$ & $\mathrm{InCl}_{3}(0.1$ equiv) & $33: 67$ & $\mathbf{5} \mathbf{a}, 58$ \\
5 & $\mathrm{Cl}(\mathbf{1 b})$ & $\mathrm{InCl}_{3}(0.1$ equiv) & $31: 69$ & $\mathbf{5} \mathbf{\prime}, 57$ \\
6 & $\mathrm{MeO}(\mathbf{1 c})$ & $\mathrm{InCl}_{3}(0.1$ equiv) & $18: 82$ & $\mathbf{5 c}, 8 ; \mathbf{5} \mathbf{c}, 67$ \\
\hline
\end{tabular}

We then considered 32CA reactions between 2,2-dicyano-3-(430 substituted)phenyloxiranes 1a-c and internal alkynes. Using methyl but-2-ynoate (6) and methyl 3-phenylpropiolate (7) without catalyst proved completely regioselective. The cycloadducts $\mathbf{8}$ and $\mathbf{9}$ respectively formed (extended reaction times were required in the case of 7) were isolated after 35 purification by column chromatography over silica gel in 44-66\% yields (Table 3 ).

What is remarkable on the ${ }^{1} \mathrm{H}$ NMR spectra of the compounds $\mathbf{8}$ is a $2.1 \mathrm{~Hz}$ coupling constant between the methyl protons $(2.44$ ppm) and H5 (6.18 ppm) (see Table 3). The presence of a methyl 40 group at C3, already shown on 8c by an NMR HMQC sequence, was confirmed by X-ray diffraction on crystals of $\mathbf{8 a}, \mathbf{b}$, allowing an unambiguous assignment (Table 3 , entries 1-3). $\dagger$
Table 3 Cycloaddition reaction between carbonyl ylides generated from the epoxides 1 and methyl but-2-ynoate and 3-phenylpropiolate $(6,7)$.

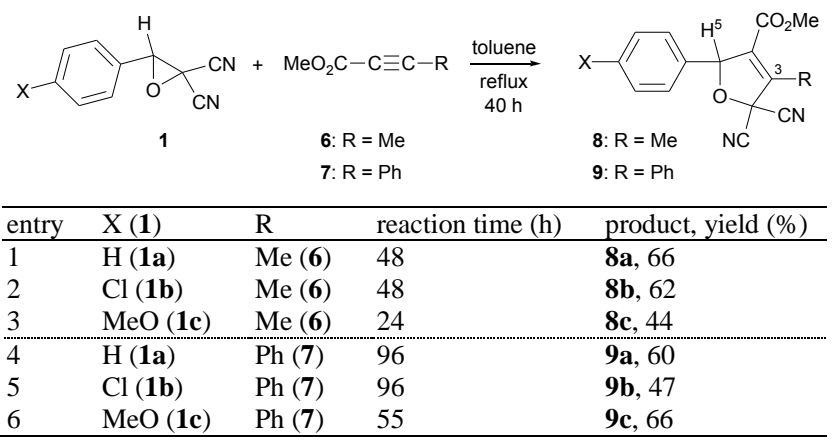

2,2-Dicyano-3-(4-chlorophenyl)oxirane (1c) was also reacted with 3-phenylpropiolonitrile (10) as before to afford the expected 45 product 11. The reaction nevertheless proved less efficient, and the cycloadduct $\mathbf{1 1}$ could not be separated from the dioxolanes $\mathbf{1 2}$ coming from a reaction with the aldehyde resulting from epoxide degradation (Scheme 1).
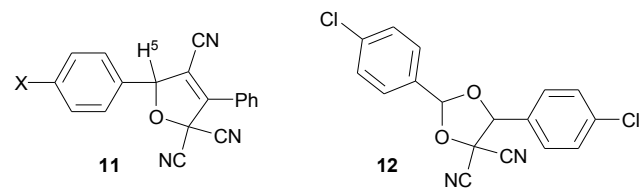

Scheme 1 The different products obtained by reaction of 2,2-dicyano-3(4-chlorophenyl)oxirane (1c) with 3-phenylpropiolonitrile (10).

\section{Calculations}

50 1) Mechanistic study of the 32CA reactions of the carbonyl ylide 1 'a with methyl propiolate (4) and methyl but-2-ynoate (6).

In order to explain the reactivity and regioselectivity of the $32 \mathrm{CA}$ reactions of the carbonyl ylide (CY) 1'a with methyl propiolate (4) and methyl but-2-ynoate (6), the mechanisms of these 55 cycloaddition reactions were theoretically studied using DFT methods at the B3LYP/6-31G* level.

The CY 1'a can adopt the $E$ or $Z$ configuration through the restricted rotation of the $\mathrm{C} 1-\mathrm{O} 2$ bond. In this way, while $(E)-\mathbf{1}$ 'a adopts a planar rearrangement, $(Z)-\mathbf{1}$ 'a is twisted as a ${ }_{60}$ consequence of the hindrance between the phenyl and one cyano group. This hindrance makes (Z)-1'a $8.6 \mathrm{kcal}^{-\mathrm{mol}^{-1}}$ higher in energy than $(E)-\mathbf{1}$ 'a. In addition, the barrier height associated with the $\mathrm{C} 1-\mathrm{O} 2$ bond rotation is very large, $27.1 \mathrm{kcal}^{\mathrm{mol}} \mathrm{m}^{-1}{ }^{5 c}$ Consequently, only the $E$ configuration of the CY 1'a is 65 considered in the present study.

Due to the asymmetry of both reagents two competitive reaction channels are feasible for each 32CA reaction. They are related to the two regioisomeric approach modes of the CY 1'a towards the alkynes $\mathbf{4}$ and $\mathbf{6}$, named $\mathbf{m}$ and $\mathbf{o}$ (the $\mathbf{m}$ and $\mathbf{o}$ 70 acronyms, traditionally used to refer to the relative meta and ortho positions in the benzene series, are here employed to distinguish the cycloadduct (CA) with distant ester and nitrile functions from that with adjacent ester and nitrile functions). Along the channel $\mathbf{m}$, the $\mathrm{C} 1-\mathrm{C} 5$ and $\mathrm{C} 3-\mathrm{C} 4$ bonds are formed, 75 while along the channel o, the $\mathrm{C} 1-\mathrm{C} 4$ and $\mathrm{C} 3-\mathrm{C} 5$ bonds are formed. The two regioisomeric channels were studied. Analysis of the stationary points associated with these 32CA reactions indicates that they have a one-step mechanism. Therefore, two 
transition states (TSs), TSxm and TSxo, and two CAs, CAxm and CAxo, were located and characterized for each $32 \mathrm{CA}$ reaction (see Scheme 2).

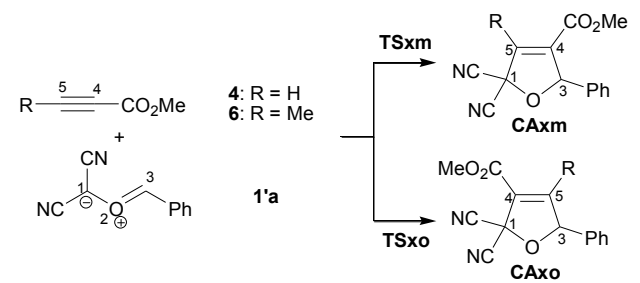

Scheme 2 32CA reactions between CY 1'a and methyl propiolate (4) or methyl but-2-ynoate (6).

The two 32CA reactions present very low activation barriers: $52.3 \mathrm{kcal} \mathrm{mol}^{-1}$ for TS1m and $3.6 \mathrm{kcal} \mathrm{mol}^{-1}$ for TS2m (see Table 4). On the other hand, the two regioisomeric TSs are 2.0 (TS1o) and 4.3 (TS2o) kcal.mol ${ }^{-1}$ higher in energy than those associated with the most favorable channels $\mathbf{m}$. These results agree entirely with the experimentally observed regioselectivity. In this way, a 10 mixture of CA1m and CA1o is expected for the 32CA reaction between 1'a and 4, while for the reaction with $\mathbf{6}$ only one CA, CA2m, is expected. Experimentally, a CA1m:CA1o 76:24 mixture is obtained. All these 32CA reactions are strongly exothermic: between -68.3 and $-72.6 \mathrm{kcal}^{\mathrm{mol}}{ }^{-1}$.

Table 4. Relative energies ( $\Delta \mathrm{E}$, in kcal.mol ${ }^{-1}$, relative to $\mathbf{1} \mathbf{a} \mathbf{a} \mathbf{4}$ and $\left.\mathbf{1} \mathbf{\prime} \mathbf{a}+\mathbf{6}\right)$ in gas phase and in toluene, and relative enthalpies $\left(\Delta \mathrm{H}\right.$, in kcal.mol $\left.{ }^{-1}\right)$, entropies $\left(\Delta \mathrm{S}\right.$, in eu) and free energies $\left(\Delta \mathrm{G}\right.$ in kcal.mol $\left.{ }^{-1}\right)$ at $110^{\circ} \mathrm{C}$ in toluene of the stationary points involved in the 32CA reactions of CY 1'a with methyl propiolate (4) and methyl but-2-ynoate (6).

\begin{tabular}{lccccc}
\hline & $\Delta \mathrm{E}$ & $\Delta \mathrm{E}_{\text {toluene }}$ & $\Delta \mathrm{H}$ & $\Delta \mathrm{S}$ & $\Delta \mathrm{G}$ \\
\hline TS1m & 2.3 & 4.4 & 4.7 & -42.3 & 20.9 \\
TS1o & 4.3 & 6.1 & 6.2 & -41.0 & 21.9 \\
CA1m & -71.9 & -68.4 & -66.2 & -47.0 & -48.1 \\
CA10 & -72.6 & -69.5 & -67.3 & -48.3 & -48.7 \\
\hline TS2m & 3.6 & 6.3 & 6.4 & -47.1 & 24.4 \\
TS2o & 7.9 & 9.8 & 9.8 & -44.2 & 26.8 \\
CA2m & -68.3 & -64.4 & -62.7 & -52.6 & -42.5 \\
CA2o & -69.5 & -66.1 & -64.4 & -51.4 & -44.6 \\
\hline
\end{tabular}

15 The B3LYP/6-31G* geometries were further optimized using the $6-311 G^{*}$ and $6-311+G^{*}$ basis sets. The energy results are given in the Supplementary Information part. A comparison of the relative energies using the three selected basis sets indicates that there are not significant differences. The activation energies 20 increase slightly with the size of the basis set, but this fact is a consequence of the higher stabilization of CY 1'a than the TSs. Anyway, the regioselectivity found at these 32CA reactions is kept no matter which basis set is used.

Recent studies devoted to 32CA reactions have shown that 25 solvent effects in the geometry optimization have poor effects due to the low polar character of both TSs and CAs, and of toluene and dichloromethane solvents. ${ }^{12}$ Consequently, solvent effects of toluene on energies were considered through singlepoint energy calculations over the gas-phase optimized 30 geometries using the PCM method. Solvent effects stabilize all species between 2 and $7 \mathrm{kcal}^{\mathrm{mol}}{ }^{-1}$ (see Table 4), with the reagents being more stabilized than the TSs. ${ }^{12}$ Therefore, the activation barrier for the cycloadditions increases by 2.1 (TS1m) and 2.7 (TS2m) kcal.mol ${ }^{-1}$. However, solvent effects do not
35 change the gas phase regioselectivity. Therefore, solvent effects appear to have little influence on these 32CA reactions.

Further thermodynamic calculations with regard to toluene showed a similar free energy difference between each pair of regioisomeric TSs (see Table 4). Adding thermal corrections to 40 energies and entropies increases the activation free energies to 20.9 (TS1m), 21.9 (TS1o), 24.4 (TS2m) and 26.8 (TS2o) kcal.mol ${ }^{-1}$. Several conclusions can be drawn from these energies: i) these free activation energies are not very high. However, the endergonic character of the formation of the CY 1'a, which rises 45 the activation free energies of these 32CA reactions to 29.6 (TS1m) and 33.1 (TS2m) kcal.mol ${ }^{-1}$, is responsible for the high temperature demanded in these thermal reactions. ${ }^{7}$ Note that the free energy of the CY 1'a is $8.7 \mathrm{kcal}^{\mathrm{m}} \mathrm{mol}^{-1}$ above than the corresponding epoxide; $;^{7}$ ii) the presence of an electron-releasing 50 methyl group in methyl but-2-ynoate (6) increases the free activation energy by $3.5 \mathrm{kcal} . \mathrm{mol}^{-1}$ relative to that using methyl propiolate $(4)$; iii) the regioselectivity measured as the activation free energy difference between the two regioisomeric TSs remains almost unaltered after the thermodynamic calculations: ${ }_{55} \Delta \mathrm{G}_{(\mathrm{TS10}-\mathrm{TS1m})}=1.0 \mathrm{kcal} . \mathrm{mol}^{-1}$ and $\Delta \mathrm{G}_{(\mathbf{T S 2 0}-\mathrm{TS} 2 \mathrm{~m})}=2.4 \mathrm{kcal} . \mathrm{mol}^{-1}$; and iv) these $32 \mathrm{CA}$ reactions are strongly exergonic: between -42.5 to $-48.7 \mathrm{kcal} . \mathrm{mol}^{-1}$. Consequently, these reactions are irreversible.

The B3LYP/6-31G* geometries of the TSs associated with the 60 32CA reactions between the CY 1'a and methyl propiolate (4) and methyl but-2-ynoate (6) are given in Figure 1, while those obtained using the $6-311 \mathrm{G}^{*}$ and $6-311+\mathrm{G}^{*}$ basis sets are given in the Supplementary Information part. At the TSs associated with the 32CA reaction between the CY 1'a and methyl propiolate (4), 65 the lengths of the $\mathrm{C}-\mathrm{C}$ forming bonds are $2.375 \AA(\mathrm{C} 1-\mathrm{C} 5)$ and $2.505 \AA(\mathrm{C} 3-\mathrm{C} 4)$ at TS1m, and $2.283 \AA$ (C3-C5) and $2.626 \AA$ (C1-C4) at TS1o, while those in the 32CA reaction involving methyl but-2-ynoate (6) are $2.487 \AA(\mathrm{C} 1-\mathrm{C} 5)$ and $2.374 \AA$ (C3$\mathrm{C} 4)$ at TS2m, and $2.415 \AA(\mathrm{C} 3-\mathrm{C} 5)$ and $2.484 \AA(\mathrm{C} 1-\mathrm{C} 4)$ at 70 TS2o. A comparison of these lengths with those obtained using the $6-311 \mathrm{G}^{*}$ and $6-311+\mathrm{G}^{*}$ basis sets indicate that there are not significant geometrical differences.

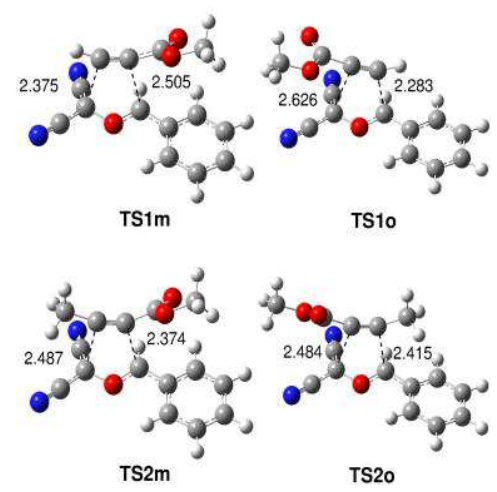

Figure 1 Transition structures involved in the reactions between CY 1'a and methyl propiolate (4) and methyl but-2-ynoate (6) (distances are given in $\AA$ ).

The electronic structure of the TSs involved in the 32CA reactions between the CY 1'a and methyl propiolate (4) and 75 methyl but-2-ynoate (6) was analyzed using the Wiberg bond $\operatorname{order}^{13}$ (BO) and charge transfer (CT) at the TSs. The extent in 
bond formation at the TSs is provided by the BOs. At the TSs associated with the 32CA reaction between the CY 1'a and methyl propiolate $(\mathbf{4})$, the $\mathrm{BO}$ values of the $\mathrm{C}-\mathrm{C}$ forming bonds are $0.22(\mathrm{C} 1-\mathrm{C} 5)$ and $0.17(\mathrm{C} 3-\mathrm{C} 4)$ at TS1m, and $0.26(\mathrm{C} 3-\mathrm{C} 5)$ 5 and $0.15(\mathrm{C} 1-\mathrm{C} 4)$ at $\mathbf{T S 1 o}$, while those in the 32CA reaction involving methyl but-2-ynoate (6) are $0.22(\mathrm{C} 1-\mathrm{C} 5)$ and 0.19 (C3-C4) at TS2m, and $0.22(\mathrm{C} 3-\mathrm{C} 5)$ and $0.18(\mathrm{C} 1-\mathrm{C} 4)$ at TS2o. Several conclusions can be drawn from these values: i) the relative low $\mathrm{BO}$ values found at the four TSs indicate that they 10 have an earlier character, in clear agreement with the very low activation energies and the high exothermic character of these processes $;{ }^{14}$ ii) the similar BO values of the two forming bonds at the TSs indicate that they do not present a marked asynchronicity in bond formation as would be expected in a polar process 15 involving asymmetric reagents; iii) in the four TSs, the $\mathrm{C}-\mathrm{C}$ bond formation at the $\beta$ position of $\mathbf{4}$ and $\mathbf{6}$ is slightly more advanced than at the $\alpha$ position.

The polar or non-polar character of these 32CA reactions was analyzed evaluating the CT at the four TSs. The natural charges 20 were shared between the CY and the alkyne frameworks. At the TSs, the charge at the CY framework is 0.05 at TS1m, 0.02 at TS1o, 0.00 TS2m and -0.01 at TS2o. These negligible CTs indicate that these $32 \mathrm{CA}$ reactions have a non-polar character.

2) Analysis based on the global reactivity indices at the ground 25 state of the reagents.

Studies devoted to Diels-Alder and 32CA reactions have shown that the analysis of the global indices defined within the context of conceptual $\mathrm{DFT}^{15}$ is a powerful tool to understand the behavior of polar cycloadditions. ${ }^{16}$ In Table 5, we report the static global 30 properties, namely, electronic chemical potential $\mu$, chemical hardness $\eta$, global electrophilicity $\omega$ and nucleophilicity $N$ of the CY 1'a and methyl propiolate (4) and methyl but-2-ynoate (6).

Table 5 Electronic chemical potential ( $\mu$, in au), chemical hardness ( $\eta$, in $\mathrm{au})$, global electrophilicity $(\omega$, in $\mathrm{eV})$ and global nucleophilicity $(N$, in $\mathrm{eV})$ values of CY 1'a and methyl propiolate (4) and methyl but-2-ynoate (6).

\begin{tabular}{lllll}
\hline & $\mu$ & $\eta$ & $\omega$ & $\mathrm{N}$ \\
\hline $\mathbf{1} \mathbf{a}$ & -4.61 & 2.47 & 4.29 & 3.28 \\
$\mathbf{4}$ & -4.42 & 6.43 & 1.52 & 1.48 \\
$\mathbf{6}$ & -4.04 & 6.32 & 1.29 & 1.92 \\
\hline
\end{tabular}

The electronic chemical potential $\mu$ of methyl propiolate (4), $\mu=-4.42 \mathrm{eV}$, and methyl but-2-ynoate $(6), \mu=-4.04 \mathrm{eV}$, is 35 slightly higher than that for the CY 1'a, $-4.61 \mathrm{eV}$. The gaps of electronic chemical potentials between reagents, $\Delta \mu$, are below $0.6 \mathrm{eV}$. These low values do not permit to establish a tendency for the flux of the CT along the cycloaddition, in clear agreement with the NBO analysis at the corresponding TSs.

40 The CY 1'a has a high electrophilicity value, $\omega=4.29 \mathrm{eV}$, being classified as a strong electrophile in the electrophilicity scale. On the other hand, the CY 1'a also has a very high nucleophilicity value, $N=3.28 \mathrm{eV}$, also being classified as a strong nucleophile in the nucleophilicity scale. Consequently, the ${ }_{45}$ CY 1'a can act as a strong electrophile towards nucleophilic species and as a strong nucleophile towards electrophilic species.

Methyl propiolate (4) and methyl but-2-ynoate (6) present low electrophilicity values, $\omega=1.52$ and $1.29 \mathrm{eV}$, respectively, being classified as marginal electrophiles. On the other hand, they 50 have somewhat low nucleophilicity values, $N=1.48$ and $1.92 \mathrm{eV}$, respectively, being also classified as poor nucleophiles. As expected, the methyl substitution in methyl but-2-ynoate (6) decreases the electrophilicity and increases the nucleophilicity of methyl propiolate (4).

55 Analysis of the reactivity indices indicates that although the CY 1'a can participate in polar 32CA reactions as a consequence of its high electrophilic and nucleophilic character, the low electrophilic and nucleophilic power of methyl propiolate (4) and methyl but-2-ynoate (6) prevent their participation in polar 60 cycloadditions. The behavior of the alkynes $\mathbf{4}$ and $\mathbf{6}$ could be responsible for the low $\mathrm{CT}$ observed at the corresponding TSs.

\section{3) ELF topological analysis of the $32 C A$ reaction between the $C Y$ 1 'a and methyl propiolate (4).}

Recent theoretical studies have shown that the topological 65 analysis of the ELF along the reaction path associated with a cycloaddition is a valuable tool for understanding the bonding changes along the reaction path. ${ }^{17}$ Consequently, a topology analysis of the ELF of some selected points along the most favorable reaction path associated with the 32CA reaction 70 between the CY 1'a and methyl propiolate (4) was performed in order to understand the bond-formation in these 32CA reactions. The $N$ populations of the most relevant ELF valence basins are listed in Table 6. A schematic picture of the attractor positions and atom numbering are shown in Figure 2.

Table 6 Valence basin populations $N$ calculated from the ELF of some selected points of the IRC associated with the most favorable regioisomeric channel of the 32CA reaction between CY 1'a and methyl propiolate (4). The CT is also included.

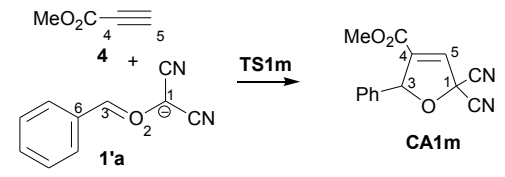

\begin{tabular}{llllll}
\hline & 1'a+4 & TS1m & P1 & P2 & CA1m \\
\hline d1(C1-C5) & & 2.375 & 2.075 & 1.767 & 1.523 \\
d2(C3-C4) & & 2.505 & 2.255 & 1.922 & 1.515 \\
\hline CT(NBO) & & 0.05 & 0.07 & 0.07 & \\
CT(ELF) & & 0.06 & 0.07 & 0.08 & \\
\hline V(C1,O2) & 1.69 & 1.54 & 1.44 & 1.34 & 1.24 \\
V(O2) & 3.57 & 3.95 & 4.38 & 2.49 & 2.59 \\
V'(O2) & & & & 2.26 & 2.45 \\
V(O2,C3) & 2.14 & 1.91 & 1.62 & 1.41 & 1.22 \\
V(C3,C6) & 2.79 & 2.69 & 2.35 & 2.17 & 2.05 \\
V(C4,C5) & 2.70 & 2.51 & 2.17 & 1.94 & 1.84 \\
V'(C4,C5) & 2.70 & 2.47 & 2.17 & 1.96 & 1.74 \\
V(C1) & 0.59 & 0.90 & 1.05 & & \\
V'(C1) & 0.58 & & & & \\
V(C3) & & & 0.46 & & \\
V(C4) & & 0.35 & 0.71 & & \\
V(C5) & & & 0.42 & & \\
V(C1,C5) & & & & 1.79 & 1.97 \\
V(C3,C4) & & & & 1.69 & 2.04 \\
\hline
\end{tabular}

75 ELF analysis of the CY 1'a shows two disynaptic basins $\mathrm{V}(\mathrm{C} 1, \mathrm{O} 2)$ and $\mathrm{V}(\mathrm{O} 2, \mathrm{C} 3)$, whose electronic populations integrate $1.69 \mathrm{e}$ and $2.14 \mathrm{e}$, respectively, one monosynaptic basin $\mathrm{V}(\mathrm{O} 2)$ integrating $3.57 \mathrm{e}$, and two monosynaptic basins $\mathrm{V}(\mathrm{C} 1)$ and $\mathrm{V}^{\prime}(\mathrm{C} 1)$, integrating $1.17 \mathrm{e}$. Recently, we studied the non-polar 80 32CA reaction between the CY 13 and tetramethylethylene (14) (see Scheme 3). ${ }^{17 b}$ ELF analysis of the CY 13 showed two pairs of monosynaptic basins $\mathrm{V}(\mathrm{Cx})$ and $\mathrm{V}^{\prime}(\mathrm{Cx})$ at each $\mathrm{C} 2$ and $\mathrm{C}^{\prime}$ 


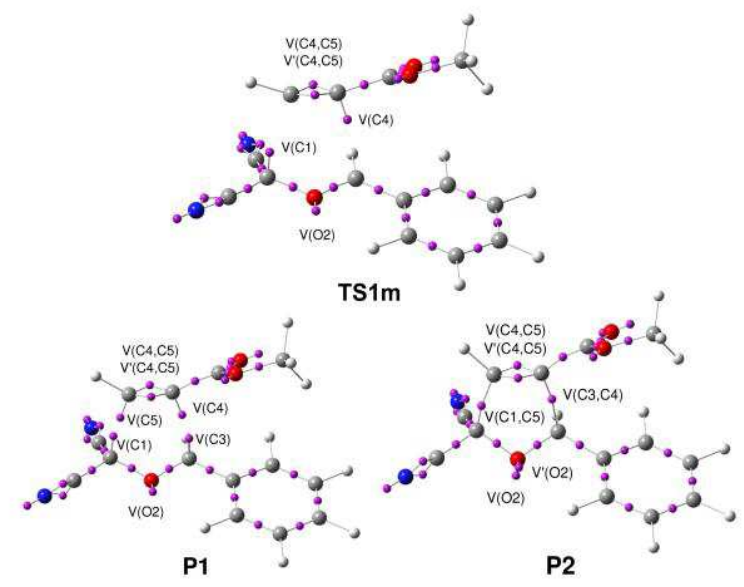

Figure 2 ELF attractors at selected points of the IRC associated with the 32CA reaction between CY 1'a and methyl propiolate (4).

carbons, integrating $c a 1.0 \mathrm{e}$ each pair, and one monosynaptic basin $\mathrm{V}(\mathrm{O} 1)$ integrating $3.58 \mathrm{e}$. The high reactivity of the CY $\mathbf{1 3}$ towards unactivated tetramethylethylene (14) was attributed to its pseudodiradical electronic structure, which allows for the $\mathrm{C}-\mathrm{C}$ 5 bond formation. Note that the activation enthalpy associated with this non-polar $32 \mathrm{CA}$ reaction was only of $4.7 \mathrm{kcal}^{\mathrm{mol}}{ }^{-1}{ }^{17 b}$ The absence of the two monosynaptic basins at the $\mathrm{C} 3$ carbon of the CY 1'a can be explained by a delocalization of the electron density of this pseudodiradical center at the adjacent phenyl 10 group. This delocalization is supported by the changes of electron density of the disynaptic basin $\mathrm{V}(\mathrm{C} 3, \mathrm{C} 6)$ along the IRC, which decreases from 2.79e in CY 1'a to 2.05e in CA1m.

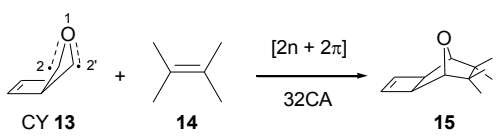

Scheme 3

On the other hand, methyl propiolate (4) has two disynaptic basins $\mathrm{V}(\mathrm{C} 4, \mathrm{C} 5)$ and $\mathrm{V}^{\prime}(\mathrm{C} 4, \mathrm{C} 5)$, integrating 5.40e. These 15 disynaptic basins account for the $\mathrm{C} 4-\mathrm{C} 5$ triple bond drawn in the Lewis structure of methyl propiolate (4).

Along the 32CA pathway, the ELF analysis of TS1m, d1 = $2.375 \AA$ and $\mathrm{d} 2=2.505 \AA$, shows that while the two monosynaptic basins $\mathrm{V}(\mathrm{C} 1)$ and $\mathrm{V}^{\prime}(\mathrm{C} 1)$ have merged into one 20 monosynaptic basin $\mathrm{V}(\mathrm{C} 1)$, integrating $0.90 \mathrm{e}$, a new monosynaptic basin $\mathrm{V}(\mathrm{C} 4)$, integrating $0.35 \mathrm{e}$, has been created at the $\mathrm{C} 4$ carbon of methyl propiolate (4). Simultaneously, the two disynaptic basins $\mathrm{V}(\mathrm{C} 4, \mathrm{C} 5)$ and $\mathrm{V}^{\prime}(\mathrm{C} 4, \mathrm{C} 5)$ belonging to the $\mathrm{C} 4-$ $\mathrm{C} 5$ triple bond region of $\mathbf{4}$ have been depopulated by $c a$. $0.40 \mathrm{e}$. ${ }_{25}$ At this point of the IRC, the CT is very low, 0.05e. This low value indicates that this cycloaddition has no polar character. Unlike polar cycloadditions in which monosynaptic basins appear at the most electrophilic center of the electrophile as a consequence of the $\mathrm{CT}$ with takes place along the nucleophilic 30 attack, in the present non-polar cycloaddition, the monosynaptic basin $\mathrm{V}(\mathrm{C} 4)$ appears as a consequence of the internal electron reorganization that takes place at the $\mathrm{C} 4-\mathrm{C} 5$ triple bond region along the reaction path.

At P1, d1 $=2.075 \AA$ and $\mathrm{d} 2=2.255 \AA$, while the 35 monosynaptic basin $\mathrm{V}(\mathrm{C} 1)$ has slightly increased its population, the monosynaptic basin $\mathrm{V}(\mathrm{C} 4)$ has reached $0.71 \mathrm{e}$. Additionally, at this point of the IRC two monosynaptic basins $\mathrm{V}(\mathrm{C} 3)$ and $\mathrm{V}(\mathrm{C} 5)$, integrating $0.46 \mathrm{e}$ and $0.42 \mathrm{e}$ respectively, have been created at the C3 carbon of the CY 1'a and at C5 carbon of 4. Simultaneously, 40 the $\mathrm{C} 4-\mathrm{C} 5$ triple bond region has been depopulated by $0.64 \mathrm{e}$. At P2, d1 = $1.767 \AA$ and $\mathrm{d} 2=1.922 \AA$, the four monosynaptic basins $\mathrm{V}(\mathrm{C} 1)$ and $\mathrm{V}(\mathrm{C} 5)$, and $\mathrm{V}(\mathrm{C} 3)$ and $\mathrm{V}(\mathrm{C} 4)$, have merged into two new disynaptic basins, $\mathrm{V}(\mathrm{C} 1, \mathrm{C} 5)$ and $\mathrm{V}(\mathrm{C} 3, \mathrm{C} 4)$, which integrate $1.79 \mathrm{e}$ and $1.69 \mathrm{e}$, respectively. Consequently, at this point of the $45 \mathrm{IRC}$, the two new $\mathrm{C} 1-\mathrm{C} 5$ and $\mathrm{C} 3-\mathrm{C} 4 \sigma$ bonds have already been formed. At P2, while the populations of the two disynaptic basins $\mathrm{V}(\mathrm{C} 4, \mathrm{C} 5)$ and $\mathrm{V}^{\prime}(\mathrm{C} 4, \mathrm{C} 5)$ have decreased to $1.94 \mathrm{e}$ and $1.96 \mathrm{e}$, the monosynaptic basin $\mathrm{V}(\mathrm{O} 2)$ present in the $\mathrm{CY} \mathbf{1}$ 'a has split into two monosynaptic basins $\mathrm{V}(\mathrm{O} 2)$ and $\mathrm{V}^{\prime}(\mathrm{O} 2)$, integrating $2.49 \mathrm{e}$ 50 and 2.26e. Finally, CA1m, d1 $=1.523 \AA$ and $\mathrm{d} 2=1.515 \AA$, presents a similar bonding pattern than that at P2. As shown in Table 6, only slight changes in the basin populations take place at the end of the reaction.

The ELF bonding analysis at TS1m indicates that the main 55 change in the electronic structure of methyl propiolate (4) is associated with the formation of $\mathrm{C} 4$ pseudoradical center. Note that at the CY 1'a, only the fusion of the two monosynaptic basins $\mathrm{V}(\mathrm{C} 1)$ and $\mathrm{V}^{\prime}(\mathrm{C} 1)$ into the monosynaptic basin $\mathrm{V}(\mathrm{C} 1)$ takes place. This change is associated with the depopulation in 60 electron density at the $\mathrm{C} 4-\mathrm{C} 5$ triple bond region. This behavior together with the very low CT at TS1m, 0.06e (ELF) and 0.05 (NBO), suggests a non-polar 32CA reaction with a pseudodiradical character. Recently, we established that the high reactivity of CYs in non-polar processes can be associated with ${ }_{65}$ their pseudodiradical character, which enables the reaction to take place through an unappreciable barrier. ${ }^{17 b}$

Finally, ELF bonding analysis at the $\mathrm{C} 1-\mathrm{O} 2-\mathrm{C} 3$ framework of the CY 1'a along the 32CA reaction shows that while the electron density of the monosynaptic basins $\mathrm{V}(\mathrm{O} 2)$ and $\mathrm{V}^{\prime}(\mathrm{O} 2)$ 70 increases from 3.57e in the CY 1'a to 5.04 e in CA1m, the electron density of the disynaptic basins $\mathrm{V}(\mathrm{C} 1, \mathrm{O} 2)$ and $\mathrm{V}(\mathrm{O} 2, \mathrm{C} 3)$ decreases from $3.83 \mathrm{e}$ in the CY 1'a to $2.46 \mathrm{e}$ in CA1m. This behavior, which is similar to that found in the non-polar $32 \mathrm{CA}$ reaction between the CY 13 and tetramethylethylene (14) in ${ }_{75}$ Scheme $3,{ }^{17 d}$ indicates that the $\mathrm{O} 2$ lone pairs of the CY 1'a do not participate in the $\mathrm{C}-\mathrm{C}$ bond formation in the 32CA reaction; while in the $\mathrm{CY} \mathbf{1}$ 'a these $\mathrm{O} 2$ lone pairs are partially delocated in the pseudoradical $\mathrm{C} 1$ and $\mathrm{C} 3$ centers, in CA1m they are mainly located at the $\mathrm{O} 2$ oxygen as a consequence of the saturation of the ${ }_{80} \mathrm{C} 1$ and $\mathrm{C} 3$ carbons after the $\mathrm{C}-\mathrm{C}$ bond formations. This behavior allows for the establishment that these 32CA reactions may be electronically classified as $[2 \mathrm{n}+2 \pi]$ processes, ${ }^{17 c, d}$ in which only the two electrons of the HOMO of the CY 1'a and the two electrons of HOMO-1 of methyl propiolate (4) participate in the ${ }_{85} 32 \mathrm{CA}$ reaction (see Figure 3).

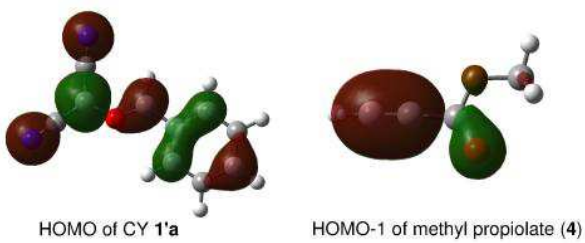

Figure 3 HOMO of CY 1'a and the two electrons of HOMO-1 of methyl propiolate (4). 
4) What is the origin of the regioselectivity in these non-polar 32 CA reactions?

While Diels-Alder reactions present a high regioselectivity, 5 which increases with the polar character of the reaction, ${ }^{18} 32 \mathrm{CA}$ reactions present a low regioselectivity, which also depends on polarity. Thus, it is expected that these non-polar 32CA reactions will have a poor regioselectivity. However, both experimental and theoretical calculations show that both reactions are 10 regioselective. Analyses of the local reactivity indices indicates that the $\mathrm{C} 1$ carbon of the CY $\mathbf{1}$ 'a is the most nucleophilic center, ${ }^{7}$ and that the $\beta$ conjugated $\mathrm{C} 5$ position of methyl propiolate (4) and methyl but-2-ynoate (6) is the most electrophilic center of these molecules. Therefore, although the polar analysis explains 15 the observed regioselectivity, the bonding pattern involved in polar cycloadditions can not rule in these non-polar 32CA reactions. $^{19}$

ELF analysis of the electronic structures of the four TSs involved in these non-polar 32CA reactions allows to obtain 20 some interesting information. For simplicity, only the ELF attractors of the four TSs are given in Figure 4. The four TSs show two monosynaptic basins, the $\mathrm{V}(\mathrm{C} 1)$ and the $\mathrm{V}(\mathrm{C} 4)$ at the regioisomeric TS1m and TS2m, and the $\mathrm{V}(\mathrm{C} 1)$ and the $\mathrm{V}(\mathrm{C} 5)$ at the regioisomeric TS1o and TS2o. Therefore, the four TSs share 25 the presence of the monosynaptic basin $\mathrm{V}(\mathrm{C} 1)$, which is already present in the CY 1'a with similar population, and the mosynaptic basins $\mathrm{V}(\mathrm{C} 4)$ in channels $\mathbf{m}$ and the $\mathrm{V}(\mathrm{C5})$ in channels $\mathbf{o}$, which are created along the reaction. Interestingly, in the four TSs, the first monosynaptic basin at the acetylenic system appears at the 30 opposite carbon of the CY, regardless of the carbonyl group position. Note that in a polar cycloaddition, these basins appear always at the $\beta$ conjugated position, which correspond with the most electrophilic center of these acetylene derivatives. ${ }^{19}$ Consequently, we can associate the relative stability of the two 35 pairs of regioisomeric TSs with the relative stability of the corresponding pseudodiradical species formed on going to the corresponding TS. Unlike the polar cycloadditions in which the formation of the monosynaptic basins takes place firstly at the $\beta$ conjugated position, in these non-polar 32CA reactions the 40 formation of the monosynaptic basin at the $\alpha$ position appears to be favored over the $\beta$ one. This finding could explain the larger regioselectivity found in the 32CA reaction using methyl but-2ynoate (6) than that with methyl propiolate (4). The presence of the electron-releasing methyl group on C5 carbon of but-2-ynoate 45 (6) favors the formation of monosynaptic basin V(C4) in TS2m respect to TS1m. This behavior is supported by the larger population of the monosynaptic basin $\mathrm{V}(\mathrm{C} 4)$ in TS2m, $0.58 \mathrm{e}$, than that in TS1m, 0.35e. Note that in both TSs, the monosynaptic basin $\mathrm{V}(\mathrm{C} 1)$ present the same population, $0.90 \mathrm{e}$.
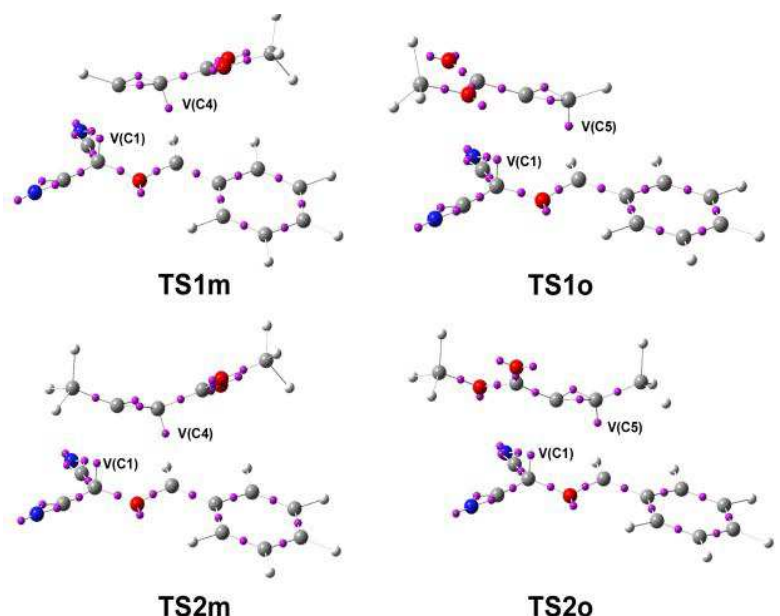

TS20

Figure 4 ELF attractors at the TSs involved in the non-polar 32CA reactions between CY 1'a and methyl propiolate (4) and methyl but-2ynoate (6).

\section{${ }_{50}$ Pharmacology}

Applying the agar plate diffusion technique, ${ }^{20}$ the newly synthesized compounds $3 \mathbf{3}, \mathbf{5}$ 'c and $\mathbf{9 c}$ were screened in vitro for their bactericidal activity against Gram positive bacteria (Staphylococcus aureus) and Gram negative bacteria 55 (Escherichia Coli and Pseudomonas aeroginosa), and for their fungicidal activity towards Fusarium oxysporium, Aspergillus niger and Candida albicans (Table 7). All the compounds tested showed moderate bactericidal activities against Staphylococcus Aureus, Escherichia Coli and Pseudomonas aeroginosa 60 compared to that of ciprofloxacin as a reference drug. The compounds tested showed moderate fungicidal activities towards Fusarium oxysporium and Aspergillus niger compared to that of nystin as a reference, except the compound 5'c that showed significant activities, in particular against Fusarium oxysporium. ${ }_{65}$ Only the compound 5'c showed a moderate activity against Candida albicans.

The compounds 3a,b, 5'c and 9c were also tested against a human liver carcinoma cell line (HEPG2), and $\mathbf{3 b}$ against human breast (MCF7), and cervix (HELA) carcinoma cell lines (Table 70 8). Moderate cytotoxic activities were observed for all the compounds tested, compared to a reference drug (doxorubicin), except in the case of $\mathbf{3 b}$, for which activities close to those of doxorubicin were observed. The difference in the value of $\mathrm{IC}_{50}$ between the two compounds $\mathbf{3 a}$ and $\mathbf{3 b}$ may be due to the 75 presence of the chloro group in $\mathbf{3 b}$, a substituent that can affect the biological activity of the compounds. ${ }^{21}$

Table 7 Bactericidal and fungicidal activity ${ }^{a}$ of the compounds $3 \mathbf{3 a}, \mathbf{5} \mathbf{c}, \mathbf{9 c}$, and ciprofloxacin and nystin.

\begin{tabular}{|c|c|c|c|c|c|c|c|}
\hline entry & compound & Staphylococcus aureus & Escherichia coli & Pseudomonas aeroginosa & Fusarium oxysporium & Aspergillus niger & Candida albicans \\
\hline 1 & $3 a$ & $19(++)$ & $17(++)$ & $17(++)$ & $19(++)$ & $20(++)$ & - \\
\hline 2 & $5 ' c$ & $27(+++)$ & $15(++)$ & $22(++)$ & $43(++++)$ & $27(+++)$ & $18(++)$ \\
\hline 3 & $9 c$ & $18(++)$ & $17(++)$ & $16(++)$ & $16(++)$ & $18(++)$ & - \\
\hline 4 & ciprofloxacin & ++++ & ++++ & ++++ & - & - & - \\
\hline 5 & nystin & - & - & - & ++++ & ++++ & ++++ \\
\hline
\end{tabular}


Table 8 In vitro cytotoxic activity $\left(\mathrm{IC}_{50}\right)^{a}$ of the compounds $3 \mathbf{3 a}, \mathbf{b}, \mathbf{5}$ 'c, $\mathbf{9 c}$, and doxorubicin against carcinoma cell lines.

\begin{tabular}{lllll}
\hline entry & compound & HEPG2 $\left(\mu \mathrm{g} \cdot \mathrm{mL}^{-1}\right)$ & $\mathrm{MCF} 7\left(\mu \mathrm{g} \cdot \mathrm{mL}^{-1}\right)$ & HELA $\left(\mu \mathrm{g} \cdot \mathrm{mL}^{-1}\right)$ \\
\hline 1 & $\mathbf{3 a}$ & 2.88 & - & - \\
2 & $\mathbf{3 b}$ & 0.67 & 0.74 & 0.89 \\
3 & $\mathbf{5} \mathbf{c}$ & 2.98 & - & - \\
4 & $\mathbf{9 c}$ & 3.34 & - & - \\
5 & doxorubicin & 0.60 & 0.70 & 0.85
\end{tabular}

${ }^{a}$ IC50 is defined as the concentration which results in a 50\% decrease in cell number as compared with that of the control structures in the absence of an inhibitor.

\section{Conclusions}

Thus, substituted 2,5-dihydrofurans were synthesized by 32CA reaction between carbonyl ylides generated from epoxides and alkynes. While 3-phenyl-5-(4-substituted phenyl)-(2H,5H)5 dihydrofuran-2,2-dicarbonitrile $\mathbf{3}$ and methyl 2,2-dicyano-5-(4substituted phenyl)-(2H,5H)-dihydrofuran-4-carboxylate 5' only dominate using phenylacetylene (2) and methyl propiolate (4), respectively, the use of methyl but-2-ynoate (6) and methyl 3phenylpropiolate (7) led to only one regioisomer, the methyl 5-(410 substituted phenyl)-2,2-dicyano- $(2 H, 5 H)$-dihydrofuran-4carboxylates $\mathbf{8}$ and $\mathbf{9}$, respectively methylated or phenylated at C3. The different observed regioisomeric ratios using methyl propiolate (4) and methyl but-2-ynoate (6) in the reactions with the CY 1'a were explained by theoretical calculations.

Despite the high electrophilic and nucleophilic character of the CY 1'a, the low electrophilic and nucleophilic character of the alkynes $\mathbf{4}$ and $\mathbf{6}$ causes that these 32CA reactions take place through a non-polar mechanism via TSs with a pseudodiradical character. In spite of the low activation energy associated with 20 these non-polar 32CA reactions, the endothermic character associated with the formation of the CY 1'a was found responsible for the high temperature required to carry out these thermal reactions. Finally, analysis of the bonding changes along these 32CA reactions allows for the classification of these non25 polar cycloadditions as $[2 n+2 \pi]$ processes.

\section{Experimental}

\section{Syntheses: general methods}

Liquid chromatography separations were achieved on silica gel Merck-Geduran Si $60(40-63 \mu \mathrm{m})$. Petrol refers to petroleum 30 ether (bp 40-60 ${ }^{\circ} \mathrm{C}$ ). Melting points were measured on a Kofler apparatus. Nuclear Magnetic Resonance spectra were acquired using a Bruker AC-300 spectrometer $(300 \mathrm{MHz}$ and $75 \mathrm{MHz}$ for ${ }^{1} \mathrm{H}$ and ${ }^{13} \mathrm{C}$ respectively). ${ }^{1} \mathrm{H}$ chemical shifts $(\delta)$ are given in ppm relative to the solvent residual peak, and ${ }^{13} \mathrm{C}$ chemical shifts 35 relative to the central peak of the solvent signal. NOESY, HMBC and HMQC experiments were performed on an Avance 500 spectrometer $\left(500 \mathrm{MHz}\right.$ and $125 \mathrm{MHz}$ for ${ }^{1} \mathrm{H}$ and ${ }^{13} \mathrm{C}$, respectively). High resolution mass spectra measurements were recorded at the Centre Régional de Mesures Physiques de l'Ouest 40 (CRMPO) in Rennes. Oxiranes were prepared according to described procedures. ${ }^{9}$ Toluene was dried before use. Reactions were performed under dry argon.

General procedure 1. A mixture of epoxide $(2 \mathrm{mmol})$ and phenylacetylene $(1.0 \mathrm{~g}, 10 \mathrm{mmol})$ in anhydrous toluene $(30 \mathrm{~mL})$
45 was heated at reflux under Ar for $40 \mathrm{~h}$. The mixture was then evaporated to dryness and the product isolated by column chromatography over silica gel (eluent: 25:75 $\mathrm{CH}_{2} \mathrm{Cl}_{2}$-petrol).

General procedure 2. A mixture of epoxide (2 mmol), phenylacetylene $(0.80 \mathrm{~g}, 8 \mathrm{mmol})$ and $\mathrm{InCl}_{3}(40 \mathrm{mg}, 0.2 \mathrm{mmol})$ in 50 anhydrous toluene $(30 \mathrm{~mL})$ was heated at reflux under Ar for $29 \mathrm{~h}$ (1a), $27 \mathrm{~h}$ (1b) and $20 \mathrm{~h} \mathrm{(1c).} \mathrm{The} \mathrm{mixture} \mathrm{was} \mathrm{then} \mathrm{evaporated} \mathrm{to}$ dryness and the product isolated by column chromatography over silica gel (eluent: 25:75 $\mathrm{CH}_{2} \mathrm{Cl}_{2}$-petrol).

3,5-Diphenyl-(2H,5H)-dihydrofuran-2,2-dicarbonitrile (3a). 55 Yield: $40 \%$ (general procedure 1), 60\% (general procedure 2). White powder, mp $133{ }^{\circ} \mathrm{C} .{ }^{1} \mathrm{H}$ NMR $\left(300 \mathrm{MHz}, \mathrm{CDCl}_{3}\right): 6.25(\mathrm{~d}$, $1 \mathrm{H}, \mathrm{J}=1.8 \mathrm{~Hz}), 6.65(\mathrm{~d}, 1 \mathrm{H}, \mathrm{J}=1.8 \mathrm{~Hz}), 7.36-7.39(\mathrm{~m}, 2 \mathrm{H})$, 7.43-7.48 (m, 3H), 7.48-7.50 (m, 3H), 7.65-7.68 (m, 2H). ${ }^{13} \mathrm{C}$ NMR (75 MHz, $\mathrm{CDCl}_{3}$ ): 73.8, 91.6, 113.1, 113.2, 126.8 (2C), ${ }_{60} 127.0$ (2C), 127.5, 129.3 (2C), 129.5 (2C), 129.8, 130.5, 131.0, 134.6, 136.5. HRMS (ESI): calcd for $\mathrm{C}_{18} \mathrm{H}_{12} \mathrm{~N}_{2} \mathrm{O}\left(\mathrm{M}^{+\bullet}\right) 272.0842$, found 272.0842 .

\section{5-(4-Chlorophenyl)-3-phenyl-(2H,5H)-dihydrofuran-2,2-}

dicarbonitrile (3b). Yield: 52\% (general procedure 1), $64 \%$ 65 (general procedure 2). Yellow powder, mp $85{ }^{\circ} \mathrm{C} .{ }^{1} \mathrm{H}$ NMR $(300$ $\left.\mathrm{MHz}, \mathrm{CDCl}_{3}\right): 6.22(\mathrm{~d}, 1 \mathrm{H}, \mathrm{J}=1.8 \mathrm{~Hz}), 6.62(\mathrm{~d}, 1 \mathrm{H}, \mathrm{J}=1.8 \mathrm{~Hz})$, $7.30(\mathrm{~d}, 2 \mathrm{H}, \mathrm{J}=8.4 \mathrm{~Hz}), 7.42(\mathrm{~d}, 2 \mathrm{H}, \mathrm{J}=8.4 \mathrm{~Hz}), 7.46-7.50(\mathrm{~m}$, $3 \mathrm{H}), 7.63-7.67(\mathrm{~m}, 2 \mathrm{H}) .{ }^{13} \mathrm{C} \mathrm{NMR}\left(75 \mathrm{MHz}, \mathrm{CDCl}_{3}\right)$ : 73.7, 90.7, 112.8, 113.1, 126.8 (2C), 127.2, 128.4 (2C), 129.5 (2C), 129.6 70 (2C), 130.5, 130.7, 134.9, 135.0, 135.7. HRMS (ESI): calcd for $\mathrm{C}_{18} \mathrm{H}_{11}{ }^{35} \mathrm{ClN}_{2} \mathrm{O}\left(\mathrm{M}^{+\bullet}\right)$ 306.0576, found 306.0455.

\section{5-(4-Chlorophenyl)-4-phenyl-(2H,5H)-dihydrofuran-2,2-}

dicarbonitrile (3'b). Yield: $12 \%$ (general procedure 1). Pale yellow oil. ${ }^{1} \mathrm{H}$ NMR (300 MHz, $\mathrm{CDCl}_{3}$ ): 6.33 (d, $1 \mathrm{H}, \mathrm{J}=2.1 \mathrm{~Hz}$ ), ${ }_{75} 6.41(\mathrm{~d}, 1 \mathrm{H}, \mathrm{J}=2.1 \mathrm{~Hz}), 7.26-7.29(\mathrm{~m}, 2 \mathrm{H}), 7.29-7.32(\mathrm{~m}, 3 \mathrm{H})$, 7.34-7.37 (m, 4H). ${ }^{13} \mathrm{C}$ NMR (75 MHz, $\left.\mathrm{CDCl}_{3}\right)$ : 72.6, 91.1, 112.7, 113.0, 127.3, 127.5 (2C), 129.1, 129.2 (2C), 129.6 (2C), 129.6, 129.7 (2C), 130.9, 134.6, 136.1. HRMS (ESI): calcd for $\mathrm{C}_{18} \mathrm{H}_{11}{ }^{35} \mathrm{ClN}_{2} \mathrm{O}\left(\mathrm{M}^{+\bullet}\right)$ 306.0576, found 306.0459.

\section{${ }_{80}$ 5-(4-Methoxyphenyl)-3-phenyl-(2H,5H)-dihydrofuran-2,2-}

dicarbonitrile (3c). Yield: 50\% (general procedure 1), $60 \%$ (general procedure 2). Yellow powder, mp $118{ }^{\circ} \mathrm{C} .{ }^{1} \mathrm{H}$ NMR $(300$ $\left.\mathrm{MHz}, \mathrm{CDCl}_{3}\right): 3.83$ (s, 3H), $6.20(\mathrm{~d}, 1 \mathrm{H}, \mathrm{J}=1.8 \mathrm{~Hz}), 6.62(\mathrm{~d}, 1 \mathrm{H}$, $\mathrm{J}=1.8 \mathrm{~Hz}), 6.94-6.97(\mathrm{~m}, 2 \mathrm{H}), 7.27-7.31(\mathrm{~m}, 2 \mathrm{H}), 7.47-7.50(\mathrm{~m}$, $\left.{ }_{85} 3 \mathrm{H}\right), 7.64-7.67(\mathrm{~m}, 2 \mathrm{H}) .{ }^{13} \mathrm{C} \mathrm{NMR}\left(75 \mathrm{MHz}, \mathrm{CDCl}_{3}\right)$ : 55.5, 73.5, 91.4, 113.1, 113.3, 114.6 (2C), 126.8 (2C), 127.6, 128.5, 128.8 (2C), 129.5 (2C), 130.5, 131.0, 134.6, 160.8. HRMS (ESI): calcd for $\mathrm{C}_{19} \mathrm{H}_{14} \mathrm{~N}_{2} \mathrm{O}_{2}\left[(\mathrm{M}+\mathrm{Na})^{+\bullet}\right]$ 302.0953, found 302.0953.

General procedure 3. A mixture of epoxide $(2 \mathrm{mmol})$ and 90 methyl propiolate $(0.67 \mathrm{~g}, 8 \mathrm{mmol}$ in the case of $\mathbf{1 a}, \mathbf{b} ; 0.16 \mathrm{~g}, 2$ $\mathrm{mmol}$ in the case of $\mathbf{1 c})$ in anhydrous toluene $(30 \mathrm{~mL})$ was heated at reflux under $\mathrm{Ar}$ for $48 \mathrm{~h}(\mathbf{1 a}, \mathbf{b})$ or $24 \mathrm{~h}(\mathbf{1 c})$. The mixture was then evaporated to dryness and the product isolated by column chromatography over silica gel (eluent: 10:90 AcOEt-petrol in the 95 case of $\mathbf{1 a}, \mathbf{b} ; 20: 80$ with $\mathbf{1 c})$.

General procedure 4. A mixture of epoxide ( $2 \mathrm{mmol})$, methyl propiolate $(0.67 \mathrm{~g}, 8 \mathrm{mmol}$ in the case of $\mathbf{1 a}, \mathbf{b} ; 0.16 \mathrm{~g}, 2 \mathrm{mmol}$ in the case of 1c) and $\mathrm{InCl}_{3}(40 \mathrm{mg}, 0.2 \mathrm{mmol})$ in anhydrous toluene $(30 \mathrm{~mL})$ was heated at reflux under Ar for $36 \mathrm{~h} \mathrm{(1a,b)} \mathrm{or} 20 \mathrm{~h}$ 
(1c). The mixture was then evaporated to dryness and the product isolated by column chromatography over silica gel (eluent: 10:90 AcOEt-petrol in the case of $\mathbf{1 a}, \mathbf{b} ; 20: 80$ with $\mathbf{1 c})$.

\section{Methyl 2,2-dicyano-5-phenyl-(2H,5H)-dihydrofuran-3- carboxylate (5a). Yield: $12 \%$ (general procedure 3). Yellow oil. ${ }^{1} \mathrm{H}$ NMR (300 MHz, $\mathrm{CDCl}_{3}$ ): 3.95 (s, 3H), 6.27 (d, 1H, J = 1.8 $\mathrm{Hz}), 7.26(\mathrm{~d}, 1 \mathrm{H}, \mathrm{J}=1.8 \mathrm{~Hz}), 7.29-7.32(\mathrm{~m}, 3 \mathrm{H}), 7.42-7.45(\mathrm{~m}$, 2H). ${ }^{13} \mathrm{C} \mathrm{NMR}\left(75 \mathrm{MHz}, \mathrm{CDCl}_{3}\right.$ ): 53.4, 72.4, 91.7, 112.0, 112.3, 126.9 (2C), 128.1, 130.2 (2C), 130.2, 134.6, 146.7, 159.1. HRMS 10 (ESI): calcd for $\mathrm{C}_{14} \mathrm{H}_{10} \mathrm{~N}_{2} \mathrm{O}_{3}\left(\mathrm{M}^{+\bullet}\right)$ 254.0589, found 254.0592.}

\begin{abstract}
Methyl 2,2-dicyano-5-phenyl-(2H,5H)-dihydrofuran-4carboxylate (5'a). Yield: $40 \%$ (general procedure 3), 58\% (general procedure 4). White powder, mp $102{ }^{\circ} \mathrm{C}$. ${ }^{1} \mathrm{H}$ NMR $(300$ $\mathrm{MHz}_{\mathrm{CDCl}}$ ): 3.73 (s, 3H), 6.24 (d, 1H, J = 2.1 Hz), 6.78 (d, 1H, $\left.{ }_{15} \mathrm{~J}=2.1 \mathrm{~Hz}\right), 7.32-7.35(\mathrm{~m}, 2 \mathrm{H}), 7.41-7.43$ (m, 3H). ${ }^{13} \mathrm{C} \mathrm{NMR}(75$ $\mathrm{MHz}, \mathrm{CDCl}_{3}$ ): 53.0, 72.3, 91.1, 111.6, 111.8, 127.6 (2C), 128.7, 129.1 (2C), 130.1, 135.1, 142.9, 160.2. HRMS (ESI): calcd for $\mathrm{C}_{14} \mathrm{H}_{10} \mathrm{~N}_{2} \mathrm{O}_{3}\left(\mathrm{M}^{+\bullet}\right)$ 254.0589, found 254.0593.
\end{abstract}

Methyl 5-(4-chlorophenyl)-2,2-dicyano-(2H,5H)20 dihydrofuran-3-carboxylate $\mathbf{( 5 b )}$. Yield: $10 \%$ (general procedure 3). Yellow oil. ${ }^{1} \mathrm{H}$ NMR (300 $\left.\mathrm{MHz}, \mathrm{CDCl}_{3}\right): 3.96$ (s, $3 \mathrm{H}), 6.24(\mathrm{~d}, 1 \mathrm{H}, \mathrm{J}=1.8 \mathrm{~Hz}), 7.23(\mathrm{~d}, 1 \mathrm{H}, \mathrm{J}=1.8 \mathrm{~Hz}), 7.24-7.27$ (m, 2H), 7.40-7.43 (m, 2H). ${ }^{13} \mathrm{C}$ NMR (75 MHz, $\left.\mathrm{CDCl}_{3}\right): 54.5$, 72.4, 90.8, 111.9, 112.2, 128.3 (2C), 128.6, 129.8 (2C), 133.1, 25 136.3, 146.0, 159.0. HRMS (APCI/ASAP): calcd for $\mathrm{C}_{14} \mathrm{H}_{8}{ }^{35} \mathrm{ClN}_{2} \mathrm{O}_{3}\left[(\mathrm{M}-\mathrm{H})^{+\bullet}\right] 287.0218$, found 287.0222.

Methyl 5-(4-chlorophenyl)-2,2-dicyano-(2H,5H)dihydrofuran-4-carboxylate (5'b). Yield: $54 \%$ (general procedure 3), 57\% (general procedure 4). White powder, mp 105 ${ }_{30}^{\circ} \mathrm{C} .{ }^{1} \mathrm{H}$ NMR $\left(300 \mathrm{MHz}, \mathrm{CDCl}_{3}\right): 3.75(\mathrm{~s}, 3 \mathrm{H}), 6.21(\mathrm{~d}, 1 \mathrm{H}, \mathrm{J}=$ $2.1 \mathrm{~Hz}), 6.78(\mathrm{~d}, 1 \mathrm{H}, \mathrm{J}=2.1 \mathrm{~Hz}), 7.26-7.29(\mathrm{~m}, 2 \mathrm{H}), 7.39-7.41$ $(\mathrm{m}, 2 \mathrm{H}) .{ }^{13} \mathrm{C} \mathrm{NMR}\left(75 \mathrm{MHz}, \mathrm{CDCl}_{3}\right): 53.1,72.3,90.3,111.4$, 111.7, 128.9, 129.0 (2C), 129.5 (2C), 133.7, 136.2, 142.6, 160.0. HRMS (APCI/ASAP): calcd for $\mathrm{C}_{14} \mathrm{H}_{8}{ }^{35} \mathrm{ClN}_{2} \mathrm{O}_{3} \quad\left[(\mathrm{M}-\mathrm{H})^{+\bullet}\right]$ 35287.0218 , found 287.0219 .

Methyl 2,2-dicyano-5-(4-methoxyphenyl)-(2H,5H)dihydrofuran-3-carboxylate $\quad \mathbf{( 5 c )}$ Yield: $11 \%$ (general procedure 3 ), $8 \%$ (general procedure 4). Yellow oil. ${ }^{1} \mathrm{H}$ NMR $\left(300 \mathrm{MHz}, \mathrm{CDCl}_{3}\right): 3.82(\mathrm{~s}, 3 \mathrm{H}), 3.96(\mathrm{~s}, 3 \mathrm{H}), 6.22(\mathrm{~d}, 1 \mathrm{H}, \mathrm{J}=$ $401.5 \mathrm{~Hz}), 6.93-6.96(\mathrm{~m}, 2 \mathrm{H}), 7.20-7.23(\mathrm{~m}, 2 \mathrm{H}), 7.24(\mathrm{~d}, 1 \mathrm{H}, \mathrm{J}=$ $1.5 \mathrm{~Hz}) .{ }^{13} \mathrm{C} \mathrm{NMR}\left(75 \mathrm{MHz}, \mathrm{CDCl}_{3}\right): 53.4,55.5,72.0,91.5$, 112.1, 112.4, 114.8 (2C), 126.4, 128.2, 128.8 (2C), 146.7, 159.2, 161.1. NMR HMQC sequences performed on $\mathbf{5 c}$ showed relationship between $\mathrm{H} 4$ and $\mathrm{C} 5$ (see Table 2). HRMS (ESI): ${ }_{45}$ calcd for $\mathrm{C}_{15} \mathrm{H}_{12} \mathrm{~N}_{2} \mathrm{O}_{4}\left(\mathrm{M}^{+\bullet}\right)$ 284.0689, found 284.0683.

Methyl 2,2-dicyano-5-(4-methoxyphenyl)-(2H,5H)dihydrofuran-4-carboxylate (5'c). Yield: $65 \%$ (general procedure 3), 67\% (general procedure 4). Yellow oil. ${ }^{1} \mathrm{H}$ NMR $\left(300 \mathrm{MHz}, \mathrm{CDCl}_{3}\right): 3.71(\mathrm{~s}, 3 \mathrm{H}), 3.79(\mathrm{~s}, 3 \mathrm{H}), 6.19(\mathrm{~d}, 1 \mathrm{H}, \mathrm{J}=$ $502.1 \mathrm{~Hz}), 6.77(\mathrm{~d}, 1 \mathrm{H}, \mathrm{J}=2.1 \mathrm{~Hz}), 6.91-6.94(\mathrm{~m}, 2 \mathrm{H}), 7.23-7.26$ $(\mathrm{m}, 2 \mathrm{H}) .{ }^{13} \mathrm{C}$ NMR $\left(75 \mathrm{MHz}, \mathrm{CDCl}_{3}\right): 52.9,55.4,71.9,90.8$, 111.6, 111.9, 114.5 (2C), 127.1, 128.5, 129.1 (2C), 142.7, 160.2, 160.8. NMR HMQC sequences performed on 5'c showed relationship between the phenyl protons and the carbonyl group.
${ }_{55} \mathrm{HRMS}$ (ESI): calcd for $\mathrm{C}_{15} \mathrm{H}_{12} \mathrm{~N}_{2} \mathrm{O}_{4}\left(\mathrm{M}^{+\bullet}\right)$ 284.0689, found 284.0689.

General procedure 5. A mixture of epoxide $(2 \mathrm{mmol})$ and methyl but-2-ynoate $(2.1 \mathrm{~g}, 22 \mathrm{mmol}$ in the case of $\mathbf{1 a}, \mathbf{b} ; 1.6 \mathrm{~g}, 16$ $\mathrm{mmol}$ in the case of 1c) in anhydrous toluene $(30 \mathrm{~mL})$ was heated 60 at reflux under Ar for $48 \mathrm{~h} \mathrm{(1a,b)} \mathrm{or} 24 \mathrm{~h} \mathrm{(1c).} \mathrm{The} \mathrm{mixture} \mathrm{was}$ then evaporated to dryness and the product isolated by column chromatography over silica gel (eluent: 5:95 AcOEt-petrol in the case of $\mathbf{1 a}, \mathbf{b} ; 10: 90$ with $\mathbf{1 c})$ followed by recrystallization in $\mathrm{CH}_{2} \mathrm{Cl}_{2}$.

${ }_{65}$ Methyl 2,2-dicyano-3-methyl-5-phenyl-(2H,5H)dihydrofuran-4-carboxylate (8a). Yield: $66 \%$ (general procedure 5). Yellow powder, mp $83{ }^{\circ} \mathrm{C} .{ }^{1} \mathrm{H}$ NMR $(300 \mathrm{MHz}$, $\left.\mathrm{CDCl}_{3}\right): 2.44(\mathrm{~d}, 3 \mathrm{H}, \mathrm{J}=2.10 \mathrm{~Hz}), 3.68(\mathrm{~s}, 3 \mathrm{H}), 6.20(\mathrm{q}, 1 \mathrm{H}, \mathrm{J}=$ $2.10 \mathrm{~Hz}), 7.28-7.31(\mathrm{~m}, 2 \mathrm{H}), 7.39-7.41(\mathrm{~m}, 3 \mathrm{H}) .{ }^{13} \mathrm{C}$ NMR $(75$ $70 \mathrm{MHz}, \mathrm{CDCl}_{3}$ ): 11.2, 52.5, 77.2, 92.2, 111.9, 112.0, 127.7 (2C), $129.0 \quad$ (2C), 129.9, 134.1, 136.1, 140.4, 161.4. HRMS (APCI/ASAP): calcd for $\mathrm{C}_{15} \mathrm{H}_{11} \mathrm{~N}_{2} \mathrm{O}_{3}\left[(\mathrm{M}-\mathrm{H})^{+\bullet}\right]$ 267.0764, found 267.0765.

Methyl 5-(4-chlorophenyl)-2,2-dicyano-3-methyl-(2H,5H)75 dihydrofuran-4-carboxylate $\mathbf{( 8 b ) . ~ Y i e l d : ~} 62 \%$ (general procedure 5). White powder, mp $105{ }^{\circ} \mathrm{C} .{ }^{1} \mathrm{H}$ NMR $(300 \mathrm{MHz}$, $\left.\mathrm{CDCl}_{3}\right): 2.45(\mathrm{~d}, 3 \mathrm{H}, \mathrm{J}=2.10 \mathrm{~Hz}), 3.70(\mathrm{~s}, 3 \mathrm{H}), 6.18(\mathrm{q}, 1 \mathrm{H}, \mathrm{J}=$ $2.10 \mathrm{~Hz}), 7.23-7.26(\mathrm{~m}, 2 \mathrm{H}), 7.37-7.40(\mathrm{~m}, 2 \mathrm{H}) .{ }^{13} \mathrm{C}$ NMR $(75$ $\mathrm{MHz}, \mathrm{CDCl}_{3}$ ): 11.2, 52.6, 77.1, 91.3, 111.7, 111.9, 129.0 (2C), 80129.3 (2C), 133.7, 134.6, 135.9, 140.8, 161.2. HRMS (APCI/ASAP): calcd for $\mathrm{C}_{15} \mathrm{H}_{10}{ }^{35} \mathrm{ClN}_{2} \mathrm{O}_{3}\left[(\mathrm{M}-\mathrm{H})^{+\bullet}\right] 301.0374$, found 301.0375 .

Methyl 2,2-dicyano-5-(4-methoxyphenyl)-3-methyl-(2H,5H)dihydrofuran-4-carboxylate (8c). Yield: $44 \%$ (general 85 procedure 5). Yellow oil. ${ }^{1} \mathrm{H}$ NMR (300 MHz, $\left.\mathrm{CDCl}_{3}\right): 2.43$ (d, $3 \mathrm{H}, \mathrm{J}=2.10 \mathrm{~Hz}$ ), 3.67 (s, 3H), 3.79 (s, 3H), 6.16 (q, 1H, J = 2.10 $\mathrm{Hz}), 6.89-6.92(\mathrm{~m}, 2 \mathrm{H}), 7.21-7.24(\mathrm{~m}, 2 \mathrm{H}) .{ }^{13} \mathrm{C} \mathrm{NMR}(75 \mathrm{MHz}$, $\left.\mathrm{CDCl}_{3}\right): 11.1,52.4,55.3,76.8,91.8,111.9,112.1,114.3$ (2C), 128.1, 129.0 (2C), 134.0, 140.0, 160.7, 161.4. An NMR HMQC 90 sequence performed on $8 \mathbf{c}$ showed a relationship between the methyl group protons connected to the dihydrofuran ring and the nitrile functions, in accordance with a methyl at $\mathrm{C} 3$ (see Table 3). HRMS (ESI): calcd for $\mathrm{C}_{16} \mathrm{H}_{14} \mathrm{~N}_{2} \mathrm{O}_{4}\left(\mathrm{M}^{+\bullet}\right)$ 298.0846, found 298.0848 .

${ }_{95}$ General procedure 6. A mixture of epoxide $(2 \mathrm{mmol})$ and methyl 3-phenylpropiolate $(0.32 \mathrm{~g}, 2 \mathrm{mmol})$ in anhydrous toluene $(30 \mathrm{~mL})$ was heated at reflux under Ar for $96 \mathrm{~h}(\mathbf{1 a}, \mathbf{b})$ or $55 \mathrm{~h}$ (1c). The mixture was then evaporated to dryness and the product isolated by column chromatography over silica gel (eluent: 5:95 100 AcOEt-petrol in the case of $\mathbf{1 a}, \mathbf{b} ; 10: 90$ with $\mathbf{1 c}$ ) followed by recrystallization in $\mathrm{CH}_{2} \mathrm{Cl}_{2}$.

Methyl 2,2-dicyano-3,5-diphenyl-(2H,5H)-dihydrofuran-4carboxylate (9a). Yield: $60 \%$ (general procedure 6). Yellow powder, mp $85{ }^{\circ} \mathrm{C} .{ }^{1} \mathrm{H}$ NMR $\left(300 \mathrm{MHz}, \mathrm{CDCl}_{3}\right)$ : $3.53(\mathrm{~s}, 3 \mathrm{H})$, $1056.40(\mathrm{~s}, 1 \mathrm{H}), 7.44-7.46(\mathrm{~m}, 5 \mathrm{H}), 7.52-7.56(\mathrm{~m}, 3 \mathrm{H}), 7.60-7.63(\mathrm{~m}$, 2H). ${ }^{13} \mathrm{C} \mathrm{NMR}\left(75 \mathrm{MHz}, \mathrm{CDCl}_{3}\right): 52.6,76.9,92.2,112.0,112.2$, 127.0, 127.7 (2C), 128.8 (2C), 129.1 (2C), 129.2 (2C), 130.1, 131.1, 135.7, 136.0, 140.2, 161.1. HRMS (APCI/ASAP): calcd for $\mathrm{C}_{20} \mathrm{H}_{13} \mathrm{~N}_{2} \mathrm{O}_{3}\left[(\mathrm{M}-\mathrm{H})^{+\cdot}\right]$ 329.0920, found 329.0924. 
Methyl 5-(4-chlorophenyl)-2,2-dicyano-3-phenyl-(2H,5H)dihydrofuran-4-carboxylate (9b). Yield: $47 \%$ (general procedure 6). White powder, mp $142{ }^{\circ} \mathrm{C} .{ }^{1} \mathrm{H}$ NMR $(300 \mathrm{MHz}$, $\left.\mathrm{CDCl}_{3}\right): 3.53(\mathrm{~s}, 3 \mathrm{H}), 6.36(\mathrm{~s}, 1 \mathrm{H}), 7.35-7.38(\mathrm{~m}, 2 \mathrm{H}), 7.42-7.45$ $5(\mathrm{~m}, 2 \mathrm{H}), 7.50-7.60(\mathrm{~m}, 5 \mathrm{H}) .{ }^{13} \mathrm{C} \mathrm{NMR}\left(75 \mathrm{MHz}, \mathrm{CDCl}_{3}\right)$ : 52.7, 76.7, 91.4, 111.8, 112.1, 126.8, 128.8 (2C), 129.1 (2C), 129.2 (2C), 129.5 (2C), 131.2, 134.3, 135.5, 136.2, 140.7, 161.0. HRMS (APCI/ASAP): calcd for $\mathrm{C}_{20} \mathrm{H}_{12}{ }^{35} \mathrm{ClN}_{2} \mathrm{O}_{3} \quad\left[(\mathrm{M}-\mathrm{H})^{+\bullet}\right]$ 363.0531, found 363.0526 .

10 Methyl 2,2-dicyano-5-(4-methoxyphenyl)-3-phenyl-(2H,5H)dihydrofuran-4-carboxylate (9c). Yield: $66 \%$ (general procedure 6). Yellow oil. ${ }^{1} \mathrm{H}$ NMR $\left(300 \mathrm{MHz}, \mathrm{CDCl}_{3}\right): 3.53$ (s, $3 \mathrm{H}), 3.83(\mathrm{~s}, 3 \mathrm{H}), 6.35(\mathrm{~s}, 1 \mathrm{H}), 6.95-6.98(\mathrm{~m}, 2 \mathrm{H}), 7.34-7.37$ (m, 2H), 7.51-7.55 (m, 3H), 7.60-7.63 (m, 2H). ${ }^{13} \mathrm{C} \mathrm{NMR} \mathrm{(75} \mathrm{MHz,}$ $\left.{ }_{15} \mathrm{CDCl}_{3}\right)$ : 52.6, 55.4, 76.5, 91.9, 112.1, 112.2, 114.5 (2C), 127.0, 127.6, 128.7 (2C), 129.0 (2C), 129.2 (2C), 131.0, 135.9, 139.9, 160.9, 161.2. HRMS (ESI): calcd for $\mathrm{C}_{12} \mathrm{H}_{16} \mathrm{~N}_{2} \mathrm{O}_{4}\left(\mathrm{M}^{+\bullet}\right)$ 360.1002 , found 360.1002 .

\section{Crystallography}

${ }_{20}$ Single crystals suitable for X-ray diffraction were grown after slow evaporation (several days at room temperature) of solutions of 3a, 3b and $\mathbf{3 c}$ in $\mathrm{CH}_{2} \mathrm{Cl}_{2}$. The samples were studied with graphite monochromatized $\mathrm{Mo}_{\mathrm{K} \alpha}$ radiation $(\lambda=0.71073 \AA)$. Xray diffraction data were collected at $T=100(2) \mathrm{K}$ for $\mathbf{3 a}, \mathbf{b}$, at $T$ ${ }_{25}=150(2) \mathrm{K}$ for $\mathbf{3 c}$, and at $T=200(2) \mathrm{K}$ for $\mathbf{5} \mathbf{a}, \mathbf{5 b}, \mathbf{8 a}, \mathbf{b}$, using APEXII Bruker-AXS diffractometer (3a-c, 5'a, 5b, 8b) or KappaCCD diffractometer (8a). The structure was solved by direct methods using the SIR97 program, ${ }^{22}$ and then refined with full-matrix least-square methods based on $\mathrm{F}^{2}$ (SHELX-97) ${ }^{23}$ with 30 the aid of the WINGX program. ${ }^{24}$ All non-hydrogen atoms were refined with anisotropic atomic displacement parameters. $\mathrm{H}$ atoms were finally included in their calculated positions. Molecular diagrams were generated by ORTEP-3 (version 1.08) ${ }^{25}$ and furnished as ESI. $\dagger$

35 Crystal data for 3a: $\mathrm{C}_{18} \mathrm{H}_{12} \mathrm{~N}_{2} \mathrm{O}, M=272.30$, monoclinic, $P$ $2_{1}, a=7.7576(3), b=6.0070(2), c=14.7572(6) \AA, \beta=93.710(2)$

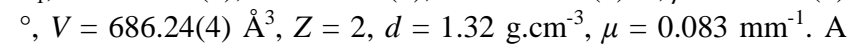
final refinement on $\mathrm{F}^{2}$ with 1721 unique intensities and 190 parameters converged at $\omega R\left(F^{2}\right)=0.067(R(F)=0.0275)$ for 401649 observed reflections with $I>2 \sigma(I)$.

Crystal data for 3b: $2\left(\mathrm{C}_{18} \mathrm{H}_{11} \mathrm{ClN}_{2} \mathrm{O}\right), \quad M=613.48$, monoclinic, $P 22_{1} / a, a=11.0917(5), b=17.5158(6), c=$ 16.2080(6) $\AA, \beta=109.615(2)^{\circ}, V=2966.2(2) \AA^{3}, Z=4, d=1.37$ g.cm $\mathrm{cm}^{-3}, \mu=0.26 \mathrm{~mm}^{-1}$. A final refinement on $\mathrm{F}^{2}$ with 6660 unique 45 intensities and 398 parameters converged at $\omega \mathrm{R}\left(\mathrm{F}^{2}\right)=0.131(\mathrm{R}(\mathrm{F})$ $=0.0449)$ for 6009 observed reflections with $\mathrm{I}>2 \sigma(\mathrm{I})$.

Crystal data for 3c: $\mathrm{C}_{19} \mathrm{H}_{14} \mathrm{~N}_{2} \mathrm{O}_{2} ; M=302.32$, triclinic, $P-1, a$ $=7.446(4), b=7.670(3), c=15.675(11) \AA, \alpha=97.60(4), \beta=$

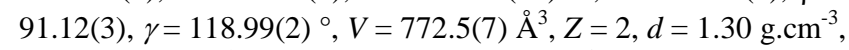
${ }_{50} \mu=0.086 \mathrm{~mm}^{-1}$. A final refinement on $\mathrm{F}^{2}$ with 3395 unique intensities and 211 parameters converged at $\omega \mathrm{R}\left(\mathrm{F}^{2}\right)=0.2758$ $(R(F)=0.0897)$ for 2690 observed reflections with $\mathrm{I}>2 \sigma(\mathrm{I})$.

Crystal data for 5'a: $\mathrm{C}_{14} \mathrm{H}_{10} \mathrm{~N}_{2} \mathrm{O}_{3}, M=254.24$, orthorhombic, $P 2_{1} 2_{1} 2_{1}, a=6.355(1), b=8.010(1), c=24.798(3) \AA, V=$ ${ }_{55} 1262.4(3) \AA^{3}, Z=4, d=1.34 \mathrm{~g}^{3} \mathrm{~cm}^{-3}, \mu=0.096 \mathrm{~mm}^{-1}$. A final refinement on $\mathrm{F}^{2}$ with 2876 unique intensities and 173 parameters converged at $\omega \mathrm{R}\left(\mathrm{F}^{2}\right)=0.0921(\mathrm{R}(\mathrm{F})=0.0391)$ for 2380 observed reflections with $\mathrm{I}>2 \sigma(\mathrm{I})$.

Crystal data for 5b: $\mathrm{C}_{14} \mathrm{H}_{9} \mathrm{ClN}_{2} \mathrm{O}_{3}, M=288.68$, monoclinic, $P$ ${ }_{60} 2{ }_{1} / c, a=11.0681(3), b=9.2126(3), c=13.3847(3) \AA, \beta=$ 90.0100(10) ${ }^{\circ}, V=1364.78(7) \AA^{3}, Z=4, d=1.40{\mathrm{~g} . \mathrm{cm}^{-3}, \mu=}^{-}, \quad$ $0.288 \mathrm{~mm}^{-1}$. A final refinement on $F^{2}$ with 3101 unique intensities and 182 parameters converged at $\omega R\left(F^{2}\right)=0.0906$ $(R(F)=0.0372)$ for 2394 observed reflections with $I>2 \sigma(I)$.

65 Crystal data for 8a: $\mathrm{C}_{15} \mathrm{H}_{12} \mathrm{~N}_{2} \mathrm{O}_{3}, M=268.27$, monoclinic, $P$ $2_{1}, a=8.5077(4), b=9.6154(5), c=9.3240(4) \AA, \beta=116.932(7)$ 。, $V=680.02(6) \AA^{3}, Z=2, d=1.31{\mathrm{~g} . \mathrm{cm}^{-3}}^{-3} \mu=0.093 \mathrm{~mm}^{-1}$. A final refinement on $\mathrm{F}^{2}$ with 1659 unique intensities and 183 parameters converged at $\omega \mathrm{R}\left(\mathrm{F}^{2}\right)=0.0784(\mathrm{R}(\mathrm{F})=0.0346)$ for 701509 observed reflections with $\mathrm{I}>2 \sigma(\mathrm{I})$.

Crystal data for $\mathbf{8 b}: \mathrm{C}_{15} \mathrm{H}_{11} \mathrm{ClN}_{2} \mathrm{O}_{3}, M=302.71$, triclinic, $P-1$, $a=6.545(1), b=10.072(2), c=11.676(2) \AA, \alpha=107.83(5), \beta=$ 101.23(4), $\gamma=92.80(3)^{\circ}, V=713.8(4) \AA^{3}, Z=2, d=1.41 \mathrm{~g} . \mathrm{cm}^{-3}$, $\mu=0.279 \mathrm{~mm}^{-1}$. A final refinement on $F^{2}$ with 3257 unique 75 intensities and 192 parameters converged at $\omega R\left(F^{2}\right)=0.0972$ $(R(F)=0.047)$ for 2050 observed reflections with $I>2 \sigma(I)$.

\section{Computational methods}

DFT calculations were carried out using the $\mathrm{B} 3 \mathrm{LYP}^{26}$ exchangecorrelation functionals, together with the standar $6-31 \mathrm{G}^{*}$ basis ${ }_{80}$ set. $^{27}$ All stationary points were further optimized using the 6$311 \mathrm{G}^{*}$ and $6-311+\mathrm{G}^{*}$ basis sets. The corresponding results are given in the Supplementary Information part. The optimisations were carried out using the Berny analytical gradient optimisation method. ${ }^{28}$ The stationary points were characterized by frequency 85 calculations in order to verify that TSs have one and only one imaginary frequency. The $\operatorname{IRC}^{29}$ paths were traced in order to check the energy profiles connecting each TS to the two associated minima of the proposed mechanism using the second order González-Schlegel integration method. ${ }^{30}$ Solvent effects 90 were considered at the same level of theory by single-point energy calculations of the gas-phase structures using a selfconsistent reaction field $(\mathrm{SCRF})^{31}$ based on the polarizable continuum model (PCM) of the Tomasi's group. ${ }^{32}$ Since this cycloaddition was carried out in toluene, we selected its dielectric 95 constant at $298.0 \mathrm{~K}, \varepsilon=2.38$. Values of enthalpies, entropies and free energies in toluene were calculated with standard statistical thermodynamics at $110^{\circ} \mathrm{C}$ and $1 \mathrm{~atm} .{ }^{27}$ The electronic structures of stationary points were analyzed by the natural bond orbital (NBO) method $^{33}$ and by the topological analysis of the ELF, $100 \eta(\mathrm{r}) .^{34}$ The ELF study was performed with the TopMod $\operatorname{program}^{35}$ using the corresponding monodeterminantal wavefunctions of the selected structures of the IRC. All calculations were carried out with the Gaussian 09 suite of programs. $^{36}$

105 The global electrophilicity index, ${ }^{37} \omega$, is given by the following simple expression, $\omega=\left(\mu^{2} / 2 \eta\right)$, in terms of the electronic chemical potential $\mu$ and the chemical hardness $\eta$. Both quantities may be approached in terms of the one electron energies of the frontier molecular orbital HOMO and LUMO, $\varepsilon_{\mathrm{H}}$ 110 and $\varepsilon_{\mathrm{L}}$, as $\mu \approx\left(\varepsilon_{\mathrm{H}}+\varepsilon_{\mathrm{L}}\right) / 2$ and $\eta \approx\left(\varepsilon_{\mathrm{L}}-\varepsilon_{\mathrm{H}}\right)$, respectively. ${ }^{38}$ Recently, we have introduced an empirical (relative) 
nucleophilicity index, ${ }^{39} \mathrm{~N}$, based on the HOMO energies obtained within the Kohn-Sham scheme, ${ }^{40}$ and defined as $\mathrm{N}=\mathrm{E}_{\mathrm{Hомо}}(\mathrm{Nu})$ $\mathrm{E}_{\mathrm{HOmo}}(\mathrm{TCE})$. The nucleophilicity is referred to TCE, because it presents the lowest HOMO energy in a large series of molecules 5 already investigated in the context of polar cycloadditions. This choice allows us conveniently to handle a nucleophilicity scale of positive values. $^{39}$

\section{Pharmacology}

Applying the agar plate diffusion technique, ${ }^{20}$ the compounds 10 were screened in vitro for their bactericidal activity against Gram positive bacteria (Staphylococcus aureus) and Gram negative bacteria (Escherichia Coli and Pseudomonas aeroginosa), and for their fungicidal activity against Fusarium oxysporium, Aspergillus niger and Candida albicans. In this method, a 15 standard $5 \mathrm{~mm}$ diameter sterilized filter paper disc impregnated with the compound $(0.3 \mathrm{mg} / 0.1 \mathrm{ml}$ of DMF) was placed on an agar plate seeded with the test organism. The plates were incubated for $24 \mathrm{~h}$ at $37{ }^{\circ} \mathrm{C}$ for bacteria and $28^{\circ} \mathrm{C}$ for fungi. The zone of inhibition of bacterial and fungi growth around the disc 20 was observed.

Compounds were tested against human liver (HEPG2), human breast (MCF7), and cervix carcinoma cell lines. The method applied is similar to that reported by Skehan et al. ${ }^{41}$ using 20 Sulfo-Rhodamine-B stain (SRB). Cells were plated in 9625 multiwell plate ( 104 cells/well) for $24 \mathrm{~h}$ before treatment with the test compound to allow attachment of cell to the wall of the plate. Different concentrations of the compound under test $(0,1.0,2.5$, 5.0 , and $10 \mu \mathrm{g} / \mathrm{ml}$ ) were added to the cell monolayer in triplicate wells individual dose, and monolayer cells were incubated with 30 the compounds for $48 \mathrm{~h}$ at $37{ }^{\circ} \mathrm{C}$ and in atmosphere of $5 \% \mathrm{CO}_{2}$. After $48 \mathrm{~h}$, cells were fixed, washed and stained with SRB stain, excess stain was washed with acetic acid and attached stain was recovered with Tris-EDTA buffer. Color intensity was measured in an ELISA reader, and the relation between surviving fraction 35 and drug concentration is plotted to get the survival curve of each tumor cell line after the specified compound and the IC50 was calculated.

\section{Acknowledgment}

The authors thank Rennes Métropole and the Institut 40 Universitaire de France for financial support to F.M. We are also grateful to the Spanish Government (project CTQ200911027/BQU).

\section{Notes and references}

${ }^{a}$ Laboratoire de Synthèse Organique Appliquée, Faculté des Sciences, 45 Université d'Oran, BP 1524 El M'Naouer, 31000 Oran, Algeria. Fax: +213-04158-2540; Tel: +213-79175-8768; E-mail: badri_sofi@yahoo.fr ${ }^{b}$ Equipe Chimie et Photonique Moléculaires, Institut des Sciences Chimiques de Rennes, UMR 6226 CNRS, Université de Rennes 1, Bâtiment 10A, Case 1003, Campus Scientifique de Beaulieu, 35042

50 Rennes Cedex, France. Fax: +33-2-2323-6955; Tel: +33-2-2323-6931; E-mail: florence.mongin@univ-rennes1.fr

${ }^{c}$ Departamento de Química Orgánica, Universidad de Valencia, Dr. Moliner 50, 46100 Burjassot, Valencia, Spain. Fax: +34-9-6354-4328; Tel: +34-9-6354-3106; E-mail: domingo@utopia.uv.es

$55{ }^{d}$ Centre de Diffractométrie X, Institut des Sciences Chimiques de Rennes, UMR 6226 CNRS, Université de Rennes 1, Bâtiment 10B, Campus Scientifique de Beaulieu, 35042 Rennes Cedex, France.
${ }^{e}$ Department of Chemistry, Faculty of Women for Arts, Science and Education, Ain Shams University, Asma Fahmy Street, Heleopolis (El60 Margany), Cairo, Egypt

$\dagger$ Electronic Supplementary Information (ESI) available: CIF file of 3a (CCDC 891057), 3b (CCDC 891058), 3c (CCDC 891059), 5'a (CCDC 891060), 5b (CCDC 891061), 8a (CCDC 891062), and 8b (CCDC 891063); ${ }^{1} \mathrm{H}$ and ${ }^{13} \mathrm{C}$ NMR spectra of the compounds 3a-c, 3'b, 5a-c, 5'a${ }_{65} \mathbf{c}, \mathbf{8 a}-\mathbf{c}$ and 9a-c; ORTEP diagrams of the compounds $\mathbf{3 a - c}, \mathbf{5} \mathbf{a}, \mathbf{5 b}, \mathbf{8 a}$ and $8 \mathbf{b}$. For the stationary points involved in the 32CA reactions of $\mathrm{CY}$ 1'a with methyl propiolate (4) and methyl but-2-ynoate (6): B3LYP/631G*, B3LYP/6-311G* and B3LYP/6-311+G* total and relative energies in vacuo and transition state geometries, $\mathrm{B} 3 \mathrm{LYP} / 6-31 \mathrm{G}^{*}$ solvent energies 70 and thermodynamic data, and B3LYP/6-31G* cartesian coordinates. See DOI:10.1039/b000000x/

1 R. Huisgen, R. Grashey and J. Sauer, in The Chemistry of Alkenes, Interscience: New York, 1964.

2 (a) A. Padwa, in 1,3-Dipolar Cycloaddition Chemistry, Wiley75 Interscience: New York, 1984, Vols. 1-2; (b) K. V. Gothelf and K. A. Jorgenson, Chem. Rev., 1998, 98, 863.

3 (a) A. Robert, J. J. Pommeret and A. Foucaud, C. R. Acad. Sci. Paris, Ser. C, 1970, 270, 1739; (b) J. J. Pommeret and A. Foucaud, Tetrahedron, 1971, 27, 2977; (c) A. Derdour and F. Texier, Can J.

$80 \quad$ Chem., 1985, 63, 2245; (d) P. Clawson, P. M. Lunn and D. A Whiting, J. Chem. Soc., Perkin Trans. 1, 1990, 159; (e) S. G. Ruf, J. Dietz and M. Regitz, Tetrahedron, 2000, 56, 6259.

4 (a) C. Yoakim, N. Goudreau, G. A. McGibbon, J. O'Meara, P. W. White and W. W. Ogilvie, Helv. Chim. Acta, 2003, 86, 3427; (b) G.-

85 W. Wang, H.-T. Yang, P. Wu, C.-B. Miao and Y. Xu, J. Org. Chem., 2006, 71, 4346.

5 (a) J. J. Pommeret and A. Robert, C. R. Acad. Sci. Paris, Ser. C, 1971, 272, 333; (b) A. Robert, J. J. Pommeret, E. Marchand and A. Foucaud, Tetrahedron, 1973, 29, 463; (c) G. Bentabed-Ababsa, A.

90 Derdour, T. Roisnel, J. A. Sáez, P. Pérez, E. Chamorro, L. R. Domingo and F. Mongin, J. Org. Chem., 2009, 74, 2120.

6 (a) A. Robert, J. J. Pommeret and A. Foucaud, Tetrahedron Lett., 1971, 12, 231; (b) A. Robert, J. J. Pommeret and A. Foucaud, Tetrahedron, 1972, 28, 2085. Concerning the $\mathrm{Rh}_{2}(\mathrm{OAc})_{4}$-catalysed 95 synthesis of 2,5-diaryl-1,3-dioxolane, see for example: (c) B. Jiang, X. Zhang and Z. Luo, Org. Lett., 2002, 4, 2453; (d) A. E. Russell, J. Brekan, L. Gronenberg and M. P. Doyle, J. Org. Chem., 2004, 69, 5269; (e) C.-D. Lu, Z.-Y. Chen, H. Liu, W.-H. Hu and A.-Q. Mi, Org. Lett., 2004, 6, 3071.

1007 G. Bentabed-Ababsa, A. Derdour, T. Roisnel, J. A. Sáez, L. R. Domingo and F. Mongin, Org. Biomol. Chem., 2008, 6, 3144.

8 K.-R. Meier, A. Linden, G. Mlostoñ and H. Heimgartner, Helv. Chim. Acta, 1997, 80, 1190.

9 M. Baudy, A. Robert and A. Foucaud, J. Org. Chem., 1978, 43, 3732. 10510 J. Pornet, L. Miginiac, K. Jaworski and B. Randrianoelina Organometallics, 1985, 4, 333.

11 P. Radha Krishna, E. Raja Sekhar and F. Mongin, Tetrahedron Lett., $2008,49,6768$.

12 W. Benchouk, S. M. Mekelleche, B. Silvi, M. J. Aurell and L. R. 110 Domingo, J. Phys. Org. Chem., 2011, 24, 611.

13 K. B. Wiberg, Tetrahedron, 1968, 24, 1083.

14 G. S. Hammond, J. Am. Chem Soc, 1955, 77, 334.

15 (a) P. Geerlings, F. De Proft and W. Langenaeker, Chem. Rev., 2003, 103, 1793; (b) D. H. Ess, G. O. Jones and K. N. Houk, Adv. Synth. 115 Catal., 2006, 348, 2337.

16 (a) L. R. Domingo, M. J. Aurell, P. Pérez and R. Contreras, Tetrahedron, 2002, 58, 4417; (b) P. Pérez, L. R. Domingo, M. J. Aurell and R. Contreras, Tetrahedron, 2003, 59, 3117.

17 (a) S. Berski, J. Andres, B. Silvi and L. R. Domingo, J. Phys. Chem.

$120 \quad$ A, 2003, 107, 6014; (b) V. Polo, J. Andres, S. Berski, L. R. Domingo and B. Silvi. J. Phys. Chem. A, 2008, 112, 7128; (c) L. R. Domingo, E. Chamorro and P. Pérez, Lett. Org. Chem., 2010, 7, 432; (d) L. R. Domingo and J. A. Sáez, J. Org. Chem., 2011, 76, 373.

18 L. R. Domingo, M. Arno and J. Andres, J. Org. Chem., 1999, 64, 5867.

19 L. R. Domingo, M. J. Aurell, P. Pérez and J. A. Sáez, RSC Adv., 2012, 2, 1334. 
20 A. W. Bauer, W. W. M. Kirby, J. C. Sherris and M. Turck, Am. J. Clin. Pathol., 1966, 45, 493.

21 See for example: M. Dolezal, J. Zitko, Z. Osicka, J. Kunes, M. Vejsova, V. Buchta, J. Dohnal, J. Jampilek and K. Kralova, Molecules, 2010, 15, 8567.

22 A. Altomare, M. C. Burla, M. Camalli, G. Cascarano, C. Giacovazzo, A. Guagliardi, A. G. G. Moliterni, G. Polidori and R. Spagna, J. Appl. Crystallogr., 1999, 32, 115.

23 G. M. Sheldrick, Acta Crystallogr., 2008, A64, 112.

1024 L. J. Farrugia, J. Appl. Crystallogr., 1999, 32, 837.

25 L. J. Farrugia, J. Appl. Crystallogr., 1997, 30, 565.

26 (a) A. D. Becke, J. Chem. Phys., 1993, 98, 5648; (b) C. Lee, W. Yang and R. G. Parr, Phys. Rev. B, 1988, 37, 785.

27 W. J. Hehre, L. Radom, P. v. R. Schleyer and J. A. Pople, in Ab initio 15 Molecular Orbital Theory, Wiley, New York, 1986.

28 (a) H. B. Schlegel, J. Comput. Chem., 1982, 3, 214-218; (b) H. B. Schlegel, in Geometry Optimization on Potential Energy Surface, Ed.: D. R. Yarkony, World Scientific Publishing, Singapore, 1994.

29 K. Fukui, J. Phys. Chem., 1970, 74, 4161.

2030 (a) C. González and H. B. Schlegel, J. Phys. Chem., 1990, 94, 5523; (b) C. González and H. B. Schlegel, J. Chem. Phys., 1991, 95, 5853.

31 (a) J. Tomasi and M. Persico, Chem. Rev., 1994, 94, 2027; (b) B. Y. Simkin and I. Sheikhet, in Quantum Chemical and Statistical Theory of Solutions-A Computational Approach, Ellis Horwood, London, 1995, p. 78.

32 (a) E. Cances, B. Mennucci and J. Tomasi, J. Chem. Phys., 1997, 107, 3032; (b) M. Cossi, V. Barone, R. Cammi and J. Tomasi, Chem. Phys. Lett., 1996, 255, 327; (c) V. Barone, M. Cossi and J. Tomasi, J. Comput. Chem., 1998, 19, 404.

3033 (a) A. E. Reed, R. B. Weinstock and F. Weinhold, J. Chem. Phys., 1985, 83, 735; (b) A. E. Reed, L. A. Curtiss and F. Weinhold, Chem. Rev., 1988, 88, 899.

34 (a) A. Savin, A. D. Becke, J. Flad, R. Nesper, H. Preuss and H. G. Vonschnering, Angew. Chem. Int. Ed., 1991, 30, 409; (b) A. Savin,

35 B. Silvi and F. Colonna, Can. J. Chem., 1996, 74, 1088; (c) A. Savin, R. Nesper, S. Wengert and T. F. Fassler, Angew. Chem. Int. Ed., 1997, 36, 1809; (d) B. Silvi, J. Mol. Struct.: THEOCHEM, 2002, 614, 3.

35 S. Noury, X. Krokidis, F. Fuster and B. Silvi, Comput. Chem., 1999, $40 \quad 23,597$.

36 M. J. Frisch, G. W. Trucks, H. B. Schlegel, G. E. Scuseria, M. A. Robb, J. R. Cheeseman, G. Scalmani, V. Barone, B. Mennucci, G. A. Petersson, H. Nakatsuji, M. Caricato, X. Li, H. P. Hratchian, A. F. Izmaylov, J. Bloino, G. Zheng, J. L. Sonnenberg, M. Hada, M. Ehara,

45 K. Toyota, R. Fukuda, J. Hasegawa, M. Ishida, T. Nakajima, Y. Honda, O. Kitao, H. Nakai, T. Vreven, J. A. Montgomery, Jr., J. E. Peralta, F. Ogliaro, M. Bearpark, J. J. Heyd, E. Brothers, K. N. Kudin, V. N. Staroverov, R. Kobayashi, J. Normand, K. Raghavachari, A. Rendell, J. C. Burant, S. S. Iyengar, J. Tomasi, M.

o Cossi, N. Rega, J. M. Millam, M. Klene, J. E. Knox, J. B. Cross, V. Bakken, C. Adamo, J. Jaramillo, R. Gomperts, R. E. Stratmann, O. Yazyev, A. J. Austin, R. Cammi, C. Pomelli, J. W. Ochterski, R. L. Martin, K. Morokuma, V. G. Zakrzewski, G. A. Voth, P. Salvador, J. J. Dannenberg, S. Dapprich, A. D. Daniels, O. Farkas, J. B.

55 Foresman, J. V. Ortiz, J. Cioslowski and D. J. Fox, Gaussian 09, Revision A.02, Gaussian, Inc., Wallingford CT, 2009.

37 R. G. Parr, L. von Szentpaly and S. Liu, J. Am. Chem. Soc., 1999, 121, 1922.

38 (a) R. G. Parr and R. G. Pearson, J. Am. Chem. Soc., 1983, 105,

607512 ; (b) R. G. Parr and W. Yang, in Density Functional Theory of Atoms and Molecules, Oxford University Press, New York, 1989.

39 (a) L. R. Domingo, E. Chamorro and P. Pérez, J. Org. Chem., 2008, 73, 4615; (b) L. R. Domingo and P. Pérez, Org. Biomol. Chem., 2011, 9, 7168 .

6540 W. Kohn and L. J. Sham, Phys. Rev. A, 1965, 140, 1133.

41 P. Skehan, R. Storeng, D. Scudiero, A. Monks, J. McMahon, D. Vistica, J. T. Warren, H. Bokesch, S. Kenney and M. R. Boyd, J. Natl. Cancer Inst., 1990, 82, 1107.
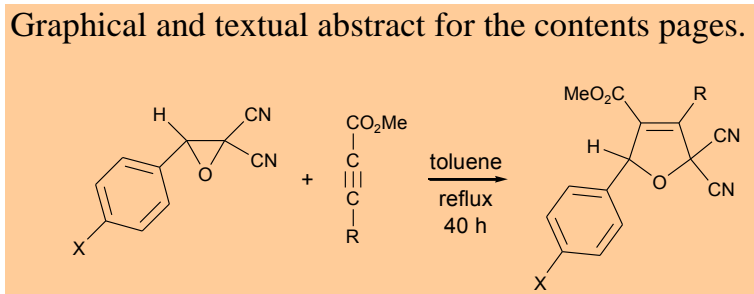

$\mathrm{X}=\mathrm{H}, \mathrm{Cl}, \mathrm{OMe}, \mathrm{R}=\mathrm{Me}, \mathrm{Ph}: 44-66 \%$ yield

Substituted 2,5-dihydrofurans were synthesized by [3+2] cycloaddition reaction between carbonyl ylides, generated from epoxides, and alkynes. The mechanism and regioselectivity were theoretically studied using DFT methods at the B $3 \mathrm{LYP} / 6-31 \mathrm{G}^{*}$ level. 